\title{
Surgical outcomes of phototherapeutic keratectomy on Epithelial basement membrane dystrophy, and the characterisation of Bowman's Layer
}

Johan Germundsson

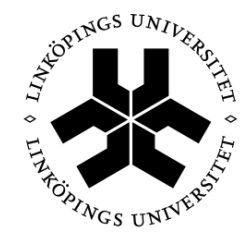

\section{Linköping University \\ FACULTY OF HEALTH SCIENCES}

Department of Ophthalmology

Linköping University, Sweden

Linköping 2014 
Surgical outcomes of phototherapeutic keratectomy on Epithelial basement membrane dystrophy, and the characterisation of Bowman's Layer

(ㄱohan Germundsson, 2014

Cover/picture/Illustration/Design: Neil Lagali / Johan Germundsson / Per Fagerholm The cover and the pictures 7B and 14 are designed by Per Lagman

Published article has been reprinted with the permission of the copyright holder.

Printed in Sweden by LiU-Tryck, Linköping, Sweden, 2014

ISBN 978-91-7519-391-5

ISSN 0345-0082 
To my parents and family, for all your love and support 



\section{TABLE OF CONTENTS}

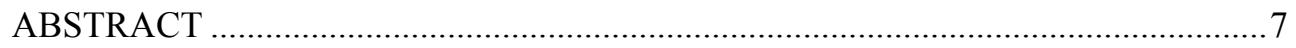

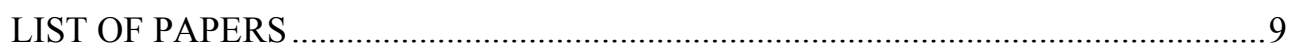

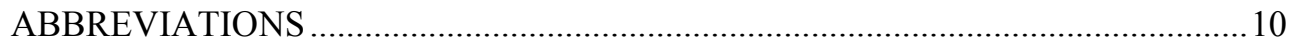

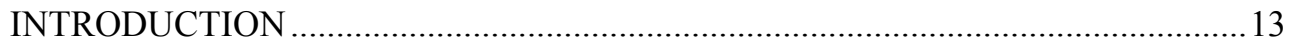

The anatomy and morphology of the cornea ........................................................13

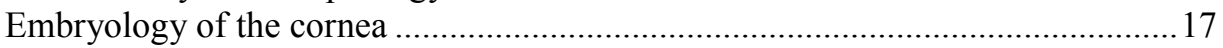

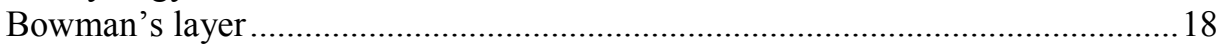

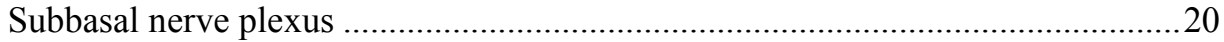

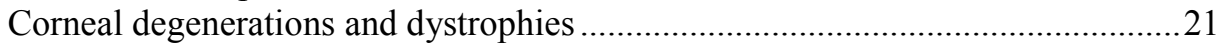

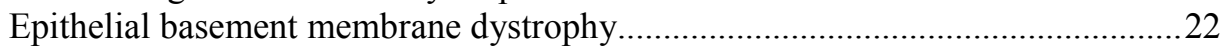

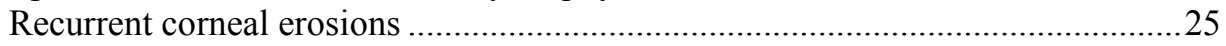

Treatment of EBMD and RCE …………..................................................25

Corneal wound healing and regeneration ...........................................................2

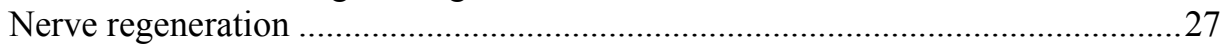

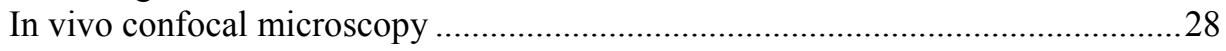

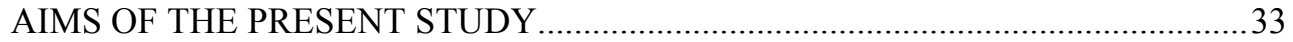

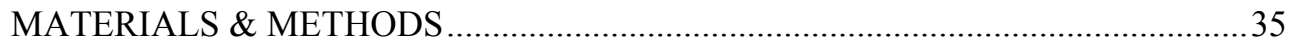

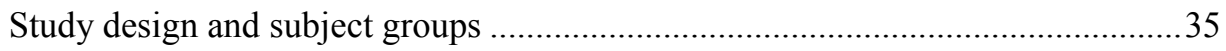

Excimer laser phototherapeutic keratectomy (Study I, II, V) ..................................36

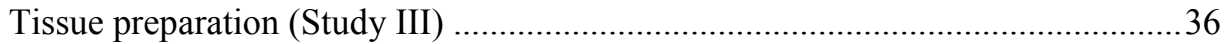

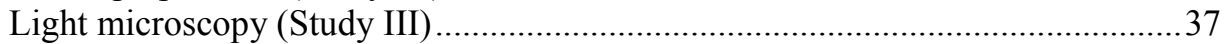

Transmission electron microscopy (Study III) ....................................................

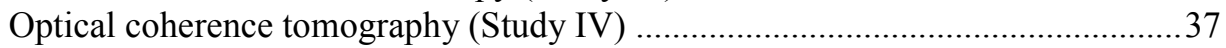

In vivo confocal microscopy (Study I -V) ............................................................. 37

Image processing and manual quantitative analysis (Study I-V) ............................39

Automated cell counting (Study V)...................................................................4

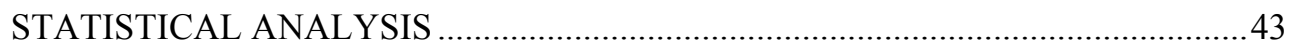

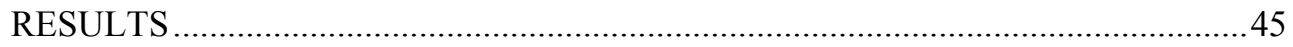

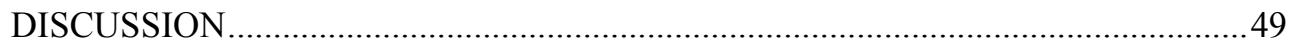

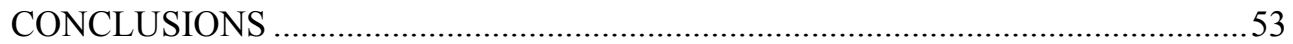

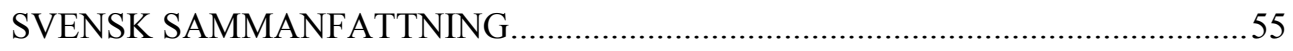

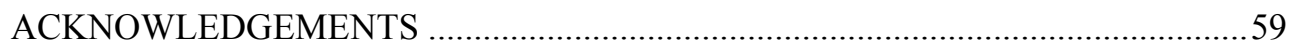

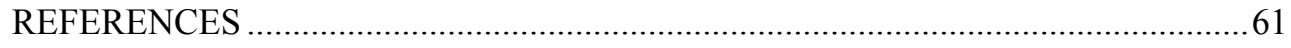

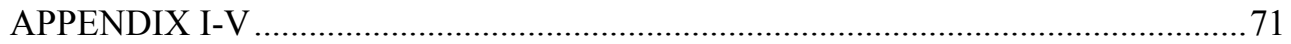





\section{ABSTRACT}

Background. Epithelial basement membrane dystrophy (EBMD) is a common disease of the anterior cornea. The disease presents a variety of symptoms and morphological signs. Most people with EBMD are asymptomatic, but approximately $10 \%$ experience problems with refraction and visual acuity and/or painful recurrent erosions of the corneal epithelium. Many different treatment options have been used, but recurrence of EBMD after treatment is a problem. Excimer laser phototherapeutic keratectomy (PTK) has become an increasingly popular surgical option in recent years, and has been used to successfully treat EBMD. When treating EBMD with PTK, the anterior corneal structures including the epithelium, Bowman's layer (BL), and subbasal nerves are disrupted or removed completely. Little is known about the microscopic effect of PTK on BL, nerves and stroma, how these structures recover after treatment, or how they could influence recurrence of EBMD after PTK treatment. Additionally, very little is known about the properties and actual thickness of BL in-vivo. At the Department of Ophthalmology, Linköping University, patients with EBMD have been treated using PTK since 2001. This cohort of previously treated patients, along with new patients receiving treatment, provided an opportunity to investigate EBMD and PTK more closely. With the acquisition of Sweden's first laser scanning in vivo corneal confocal microscope (IVCM) in 2007, a unique opportunity emerged to investigate the anterior corneal structures at the microscopic, cellular level in patients non-invasively.

Aims. To evaluate the effect of PTK treatment on EBMD clinically, and to investigate and quantify the impact of EBMD and PTK on the anterior structures of cornea including epithelium, Bowman's layer, and subbasal nerves.

Method. The Technolas 217 excimer laser system was used to treat EBMD patients at the Department of Ophthalmology during the period 2001-2010. Diagnosis and surgeries were performed using a standard clinical protocol until 2008. After 2008, IVCM was additionally used to perform pre- and postoperative examinations. In particular, images of anterior corneal structures, cells, and nerves in high-resolution were obtained. Additionally, a group of over 100 healthy volunteers underwent a full ophthalmic examination including IVCM. Other subjects examined in this work included a group of 17 patients who underwent fullthickness transplantation of the cornea. 
Results and conclusions. Clinical follow-up revealed that PTK is an effective method of alleviating the clinical symptoms of EBMD, but the dystrophy can recur with time. Bowman's layer was found to play a role in regenerative wound healing after PTK, and was also found to be important regarding the treatment and recurrence of EBMD. BL may present a physical barrier that protects the subepithelial nerve plexus thereby facilitating sensory recovery, and BL may also serve as a barrier that prevents direct traumatic contact with the corneal stroma, avoiding a stromal wound healing response. In some cases of EBMD, partial ablation of BL using PTK may not be sufficient to prevent recurrence of the underlying disease.

IVCM was found to be a useful screening tool pre- and postoperatively for detecting morphologic features in the EBMD cornea not found in slit lamp examinations. IVCM could prevent patients with symptoms, but no visible signs of EBMD on slit lamp examination, to go undiagnosed and untreated.

To aid in accurate assessment of BL in patients, an in vivo method for determining BL thickness was developed. This method could be an important tool to aid in clinical assessment and planned treatments of the anterior cornea. Using this tool, a large inter-individual variability in BL thickness and a strong negative correlation of BL thickness with age were found in a healthy population.

Using IVCM, it was also found that subbasal nerves are pathologically reduced in EBMD compared to a healthy population, and that this nerve deficit does not improve in the long term after PTK treatment. A fully automated analysis technique for quantifying corneal epithelial cells from IVCM images was additionally developed, providing an objective, standardized method to quantify and compare corneal cell densities in future scientific research. 


\section{LIST OF PAPERS}

This thesis is based on the following papers, which will be referred to in the text by their Roman numerals.

I. Lagali N, Germundsson J, Fagerholm P. The role of Bowman's layer in corneal regeneration after phototherapeutic keratectomy: a prospective study using in vivo confocal microscopy. Invest Ophthalmol Vis Sci. 2009 Sep;50(9):4192-8

II. Germundsson J, Fagerholm P, Lagali N. Clinical outcome and recurrence of epithelial basement membrane dystrophy after phototherapeutic keratectomy a cross-sectional study. Ophthalmology. 2011 Mar;118(3):515-22

III. Germundsson J, Fagerholm P, Koulikovska M, Lagali NS. An accurate method to determine Bowman's layer thickness in vivo in the human cornea. Invest Ophthalmol Vis Sci. 2012 Apr 30;53(4):2354-9

IV. Germundsson J, Karanis G, Fagerholm P, Lagali N. Age-related thinning of Bowman's layer in the human cornea in vivo. Invest Ophthalmol Vis Sci. 2013 Sep 11;54(9):6143-9

V. Germundsson J, Lagali N. Pathologically reduced subbasal nerve density in epithelial basement membrane dystrophy is unaltered by phototherapeutic keratectomy treatment. Invest Ophthalmol Vis Sci. 2014 Mar 25;55(3):183541 


\section{ABBREVIATIONS}

EBMD

MDF

RCE

BL

BM

PTK

PRK

PK

D

ANOVA

LOA

SD

RE

LE

OD

$\mathrm{OS}$

UCVA
Epithelial Basement Membrane Dystrophy

Map Dot Fingerprint Dystrophy

Recurrent Corneal Erosions

Bowman's Layer

Basement Membrane

Phototherapeutic Keratectomy

Photorefractive Keratectomy

Penetrating Keratoplasty

Diopter

Analysis of Variance

Limits of Agreement

Standard Deviation

Right Eye

Left Eye

Oculus Dexter

Oculus Sinister

Uncorrected Visual Acuity 
BCVA Best Corrected Visual Acuity

BSCVA Best Spectacle Corrected Visual Acuity

SE

Spherical Equivalent

Excimer

Excited Dimer

LM

Light Microscopy

IVCM

In vivo Confocal Microscopy

TSCM

Tandem Scanning Confocal Microscope

SSCM

Slit Scanning Confocal Microscope

LSCM

Laser Scanning Confocal Microscope

TEM

Transmission Electron Microscopy

OCT

Optical Coherence Tomography 


\section{INTRODUCTION}

\section{The anatomy and morphology of the cornea}

The cornea is a transparent dome-shaped structure located centrally in the front of the eye (Figure 1A). It is essential for human vision as it lets light into the eye, and it provides a focusing function and helps to maintain structural integrity of the eye. The optical properties are determined by the cornea's transparency, smoothness, curvature, and refractive index. The cornea provides approximately two-thirds of the refractive power of the eye, and works together with the lens to focus light onto the retina. The corneal surface also helps to protect the eye against infections and damage to deeper, interior structures. It is an avascular tissue, supplied with oxygen and nutrients from the tear film, limbal blood vessels and aqueous humor. The avascularity, fluid balance and the composition of the different cell and collagen layers in the cornea facilitate its transparency. Tight junctions and metabolic pump systems in the endothelium maintain the fluid balance $[1,2]$.
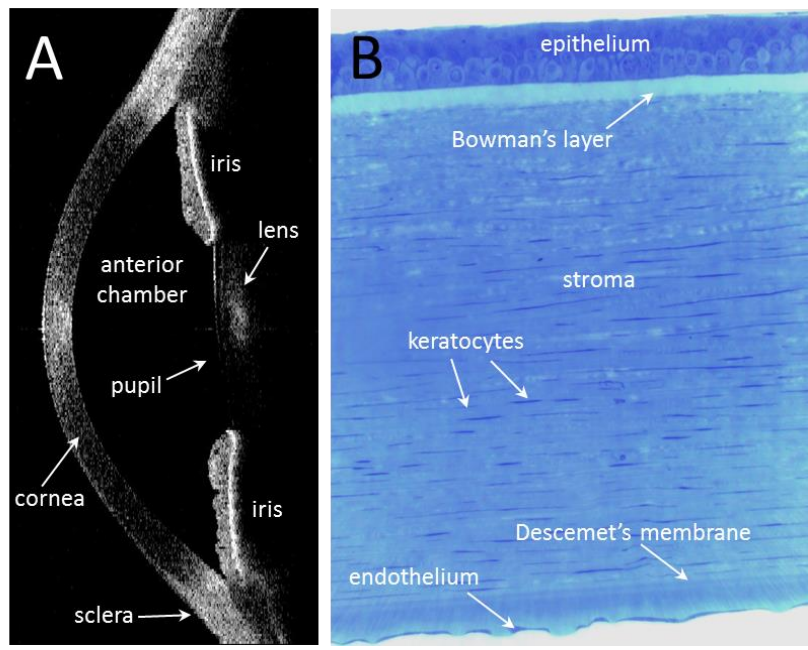

Figure 1. The human corneal anatomy. (A) In vivo cross section of the cornea and anterior eye by anterior segment optical coherence tomography. The bright areas indicate light scatter while the dark areas are transparent. (B) Histologic cross section view of the human cornea with toluidine blue staining, indicating the five principal layers of the normal cornea, as well as stromal keratocytes. 


\section{Basic corneal anatomy}

The normal human cornea is approximately $520 \mu \mathrm{m}$ thick in the centre, increasing to $650 \mu \mathrm{m}$ in the periphery [3]. The cornea consists of five distinct layers that are easily identified in light microscopy sections (Figure 1B) [1].

\section{Corneal epithelium}

The corneal epithelium together with the tear film and conjunctiva constitutes the ocular surface. The epithelium is non-keratinized and consists of arranged cell layers. It is approximately $50 \mu \mathrm{m}$ thick [3,4]. Within these cell layers, three subtypes of cells can be discerned (Figure 2). The most posterior (innermost) layer of the epithelium consists of one layer of columnar basal epithelial cells. The next 2-3 intermediate layers of epithelium anterior to the basal epithelium cells are the wing cells, responsible for the lateral stability and intercellular communication. The most anterior cell layers are called superficial epithelial cells, which are composed of 2 layers of flat polygonal cells covered by small hair-like structures (microvilli) projecting from the surface [1] to increase the adherence surface area for mucin, oxygen and nutrients of the tear film. Tight junctions at the cell margins provide a permeability barrier against solutes [5]. Epithelial cells are adherent to one another by a mechanical junction called desmosomes [1].

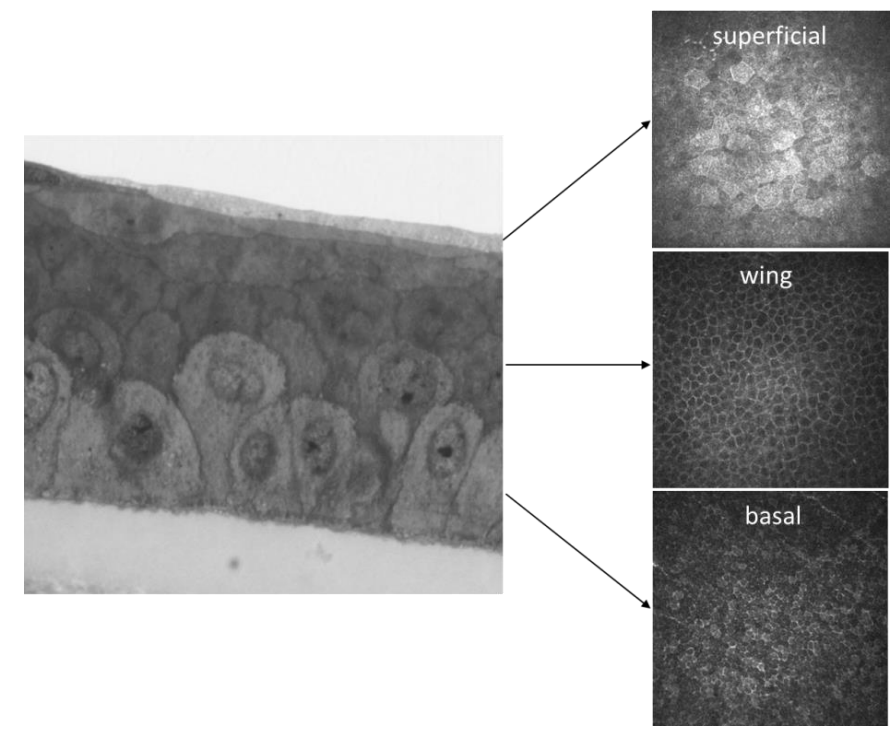

Figure 2. The three subtypes of epithelial cells in the human cornea are arranged in layers. Left image: histological cross section image of the corneal epithelium. Right images: corresponding in vivo images taken en face, or parallel to the corneal surface. 
The corneal epithelium is constantly renewing itself. This cell turnover is necessary for maintaining a smooth, healthy ocular surface, by the replacement of older worn cells with new ones. Epithelial stem cells thought to exist in specialized epithelial structures called the limbal Palisades of Vogt located in the corneal limbus area are essential for the production of new epithelial cells to facilitate the normal turnover of the epithelium $[6,7]$. The new cells migrate from the limbus to the centre. According to the $\mathrm{X}+\mathrm{Y}=\mathrm{Z}$ hypothesis by $\mathrm{R}$. Thoft [8], corneal epithelial maintenance can be defined by the the equilibrium between the proliferation of basal epithelial cells (X), the contribution to the cell mass by centripetal migration of the peripheral cells $(\mathrm{Y})$, and the shedding of cells from the surface (Z) [9]. Cell division occurs first in the basal cells. These cells migrate upwards and differentiate to wing cells, which in turn mature and differentiate into flat superficial cells. The turnover rate of the superficial epithelial cells is approximately 7 days before the superficial cells desquamate into the tear film [10]. The corneal epithelium is continuous with the conjunctival epithelium, however the corneal epithelium is transparent whereas the conjunctival epithelium is opaque, and it is the limbal barrier (and associated stem cells) that keeps the corneal and conjunctival epithelium separated. Langerhans cells (dendritic cells, part of the immune system) can be found throughout the entire cornea, but are most prevalent in the periphery [11].

\section{Basement membrane}

The basal epithelial cells secrete extracellular material (Type IV collagen, laminin, heparin, fibronectin and fibrin) giving rise to a basal lamina underlying the basal epithelial cell layer. This basal lamina is often referred to as the 'epithelial basement membrane'. Hemidesmosomes, anchoring plaques and anchoring fibrils adhere the epithelium to the basement membrane and to the underlying Bowman's layer $[5,12,13]$.

\section{Bowman's layer}

Bowman's layer (BL) is located between the epithelial basement membrane and the corneal stroma [14]. It is an acellular, compact collagenous layer thought to maintain the cornea's shape and protect it against trauma [15]. Bowman's layer is sometimes called membrane, but Bowman's layer does not have the properties of other basement membranes and does not stain with Periodic acid-Schiff (PAS), characteristic of membranes [2].

\section{Corneal stroma}

The stroma constitutes $90 \%$ of the corneal thickness. It consists of about $80 \%$ water, while the remaining components are cells (keratocytes) and extracellular 
material (proteoglycans and collagen) [5]. The stroma consists of long, narrow collagen fibrils (mainly type I, III, V and VI collagen) [16, 17] that are strictly ordered in 200-250 sheets or lamellae. Collagen fibril diameter is approximately $25-35 \mathrm{~nm}[18,19]$. To maintain transparency and minimize light scatter, the collagen fibrils within a lamella run parallel to each other, while adjacent lamellae are arranged at different relative angles between $0^{\circ}$ and $90^{\circ}$ [20]. The collagen fibrils are surrounded by an extracellular matrix to maintain a constant separation distance. Besides collagen, the extracellular matrix consists of proteoglycans. The main proteoglycans are keratan sulfate and dermatan sulfate, which are believed to be important for regulating collagen spacing and fluid balance, with the ability to absorb and retain water [5]. 3-5\% of the stromal volume is occupied by keratocytes responsible for maintaining the collagen fibrils and extracellular matrix by synthetic activity [1].

\section{Descemet's membrane}

Descemet's membrane is secreted by endothelial cells and serves as the modified basement membrane of the corneal endothelium. This layer is acellular and is composed mainly of collagen type IV and VIII fibrils, laminin, heparin sulfate, and dermatan sulfate [2, 17]. It is composed of an anterior banded segment and a posterior non-banded segment. The anterior segment is produced in utero, while the posterior segment increases in thickness throughout life. The thickness of Descemet's membrane is around $9-12 \mu \mathrm{m}$, depending on the subject's age [21, 22].

\section{Corneal endothelium}

The corneal endothelium is a single layer of hexagonal shaped cells approximately 4-6 $\mu \mathrm{m}$ thick covering the posterior corneal surface. The endothelial cells perform an important pump function responsible for regulating fluid and solute transport between the corneal stroma and the aqueous humor. If the endothelium can no longer maintain a proper fluid balance, the stroma will swell with excess fluid, disrupting the ordered arrangement of collagen, resulting in excess light scatter and the subsequent loss of transparency. Endothelial cell density decreases with age but unlike the corneal epithelium, the cells of the endothelium are post-mitotic and do not divide or regenerate. Instead, when an endothelial cell dies, the surrounding endothelial cells stretch to fill in the gap and compensate for dead cells. This reduces the overall cell density of the endothelium and increases the risk that the endothelium's pump function is compromised [1].

\section{Corneal innervation}

Apart from the distinct layers of the cornea, an important anatomical feature of the cornea is that it is densely innervated with the sensory ciliary nerve fibres via 
the ophthalmic division of the trigeminal nerve. The cornea is one of the most sensitive tissues of the body, providing sensitivity of the ocular surface to protect the cornea through a blink reflex. Nerves are also important to maintain a proper physiologic function of the epithelium and tear film, by secreting growth and maintenance factors, and stimulating secretion of the tear film [23]. Anatomically, nerve trunks enter the posterior two thirds of the cornea from the sclera, loose their myelin sheaths within 1-2 mm after entry and continue into the cornea surrounded only by Schwann cell sheaths. The nerves later subdivide into a network in the stroma $[23,24]$. These stromal nerve fibers branch anteriorly from the middle third of the stroma, forming a subepithelial plexus under Bowman's layer. The nerves then penetrate Bowman's layer losing the Schwann cells, and forming a subbasal plexus that gives rise to the naked terminal endings at the at the superficial epithelial cell level [25-30].

\section{Embryology of the cornea}

The formation of the human cornea begins at around 5-6 weeks of gestation. The surface ectoderm (the outermost of the three primitive germ layers of the embryo) invaginates into the optic cup and then after producing the lens vesicle, the surface layers separate and form the epithelium and later the epithelium secretes the basement membrane [31]. From the neural crest (a band of neuroectodermal cells) the stroma is later composed from collagen fibrils between the lens and the epithelium. At first the stroma is acellular, but is later invaded by migrating fibroblasts that will become keratocytes. Mesenchymal cells (pluripotent cells also from the cranial neural crest) form the endothelium [1]. Around week 19 of gestation, Bowman's layer is formed and according to Tisdale et al., it is the corneal epithelium that contributes to the development of this layer [32]. Other authors describe that Bowman's layer originates from the neural crest and is a condensation of the stroma generated by anterior lamellar keratocytes [3]. At the end of the first trimester, the stroma is invaded by neural processes and nerve endings then penetrate through the epithelial basal lamina into the epithelium [3]. Hemidesmosomes begin to form along the basal cell membrane in the second trimester [1]. 


\section{Bowman's layer}

Bowman's layer (BL) is an acellular collagenous layer located between the epithelial basement membrane and the anterior corneal stroma [14]. It is composed of small, randomly-oriented collagen fibrils (mainly Type I, V and VII) as well as proteoglycans. Collagen Type III and VI have also been detected in BL [17, 33]. Compared to the stroma, there is a greater presence of collagen type $\mathrm{V}$ than type I in Bowman's layer [34, 35] making the diameter of the fibrils in BL about two-thirds of the diameter of the stromal fibrils [1, 2, 5, 36]. Bowman's layer is characterized by a smooth anterior surface facing the epithelial basement membrane and an indistinct posterior surface where it merges with the less dense, but ordered, collagen lamellae of the corneal stroma proper [14] (Figure 3).
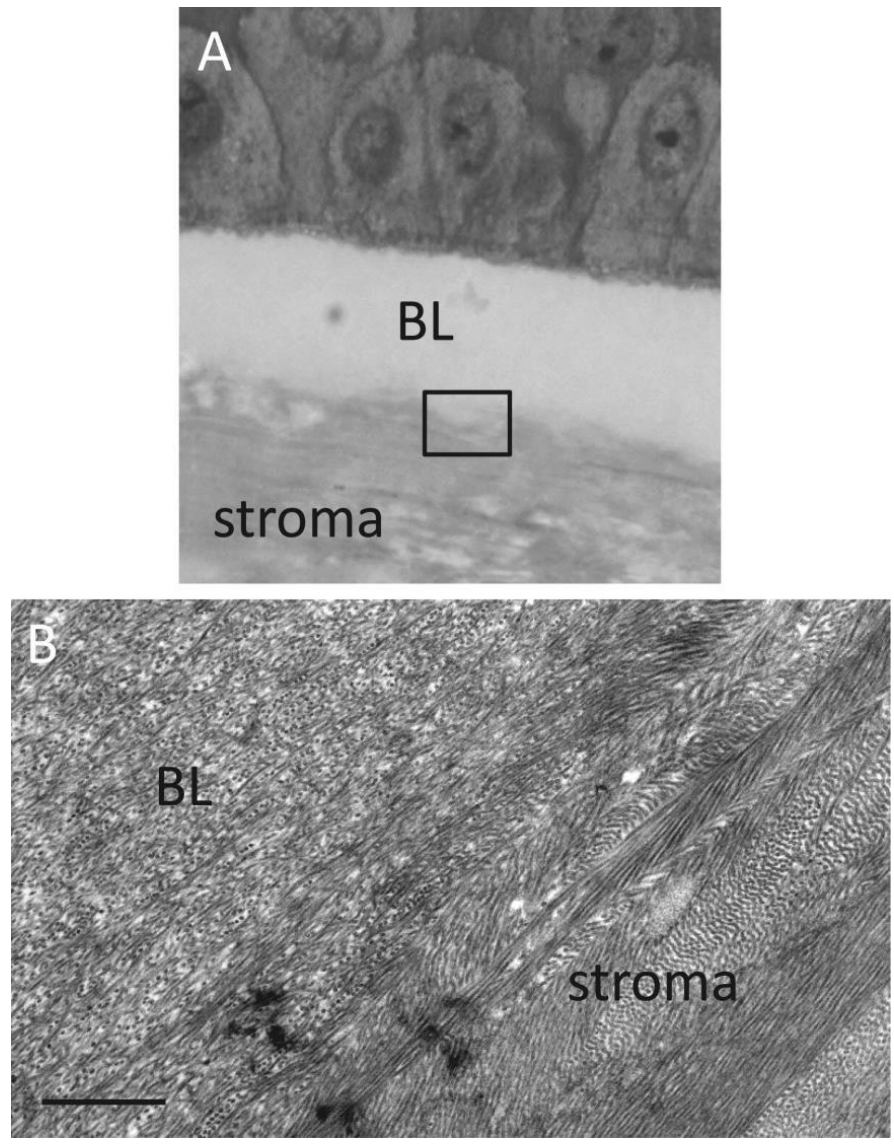

Figure 3. The transition of Bowman's Layer (BL) collagen to anterior stromal collagen. (A) In light microscopy, this transition is indistinct. (B) Electron microscopy image corresponding approximately to the rectangular area in (A) reveals a gradual transition of the randomly-oriented collagen fibrils of BL to the more ordered fibril arrangement into lamellae within the stroma. $\mathrm{Bar}=1 \mu \mathrm{m}$. 
Non-myelinated nerve axons penetrate BL irregularly across the cornea to ultimately provide epithelial innervation. Bowman's layer is well developed in higher mammals (cattle), lower mammals (rodents) have a thin BL and tadpoles completely lack BL [37]. BL does not regenerate after injury, but injuries to this layer are often replaced by disordered, collagenous scar tissue [38]. The precise functional role of $\mathrm{BL}$ is unclear. Previous studies have found that BL protects the cornea from trauma and helps to maintain the cornea's shape [15]. BL has been found important for maintaining a barrier to the corneal stroma, impacting wound healing and nerve regeneration [38]. It has also been postulated that BL may be superfluous to human corneal function, considering the absence of adverse complications in hundreds of thousands of eyes that lack BL after having undergone excimer laser photorefractive keratectomy (PRK) [39]. For anterior corneal surgery, the thickness of BL should be known accurately for planning precision ablation, however, there is very little data available concerning the thickness of BL in vivo in humans. Previous measurements of human BL thickness have had widely varying results, ranging from 8 to $17.7 \mu \mathrm{m}$, depending on the type of measurement (in vivo or ex vivo), tissue preparation method, and the measurement technique used. The techniques used to date include light microscopy (LM) [4], transmission electron microscopy (TEM)[37, 40], tandem scanning confocal microscopy (TSCM) [41], and spectral domain optical coherence tomography (SD-OCT) [42] (Table 1).

\begin{tabular}{||l|l|l|l|l||}
\hline Author/Year & Method & In-vivo? & N & $\begin{array}{l}\text { Thickness } \\
(\mu \mathrm{m})\end{array}$ \\
\hline \hline Ehlers N (2010) & LM & No & 82 & $8.56 \pm 2.76$ \\
\hline Hayashi S (2002) & TEM & No & 2 & 10 approx. \\
\hline Komai Y (1991) & TEM & No & 8 & $8-12$ \\
\hline Li H (1997) & TSCM & Yes & 7 & $16.6 \pm 1.1$ \\
\hline Tao et al. (2011) & SD-OCT & Yes & 44 & $17.7 \pm 1.6$ \\
\hline
\end{tabular}

Table 1. Summary of studies reporting the thickness of Bowman's layer in humans. N = number of samples. $\mathrm{LM}=$ light microscopy; TEM = transmission electron microscopy; TSCM = tandem scanning confocal microscopy; SD-OCT = spectral domain optical coherence tomography. 


\section{Subbasal nerve plexus}

The subbasal nerve plexus, located between Bowman's layer and the basal epithelium, is a landmark that can easily be monitored in vivo owing to the concentration of nerves at this plane and the ease of imaging this layer with high contrast by confocal microscopy (Figure 4). Therefore many studies have used it to assess nerve regeneration in the cornea. The subbasal nerves gently spiral inwards from the periphery to the corneal apex, and may follow the pattern of epithelial cells as they regenerate $[43,44]$. Notably, the subbasal nerves have been shown to be perturbed in many pathologies (such as keratoconus) and in cases of trauma $[45,46]$.
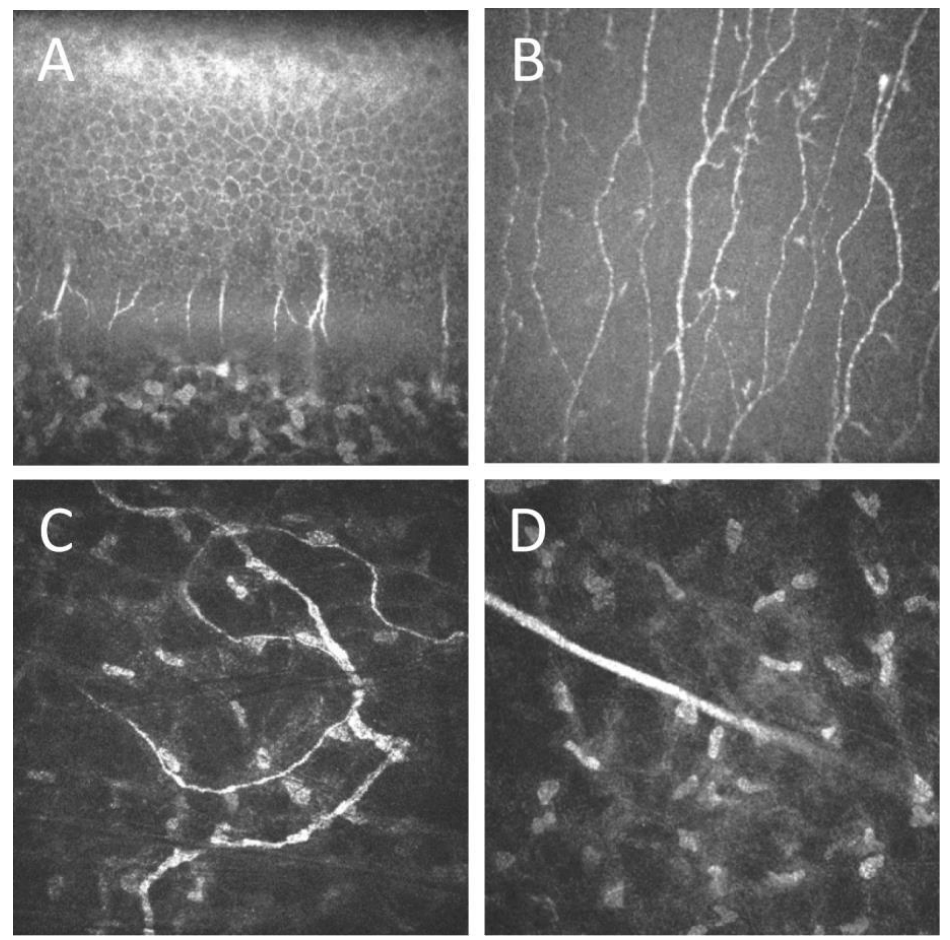

Figure 4. Human corneal nerves imaged in vivo by confocal microscopy. (A) Oblique, cross section image indicating the location of the subbasal nerve plexus anterior to Bowman's layer and posterior to the basal epithelium. (B) En face image of the subbasal nerve plexus. (C) Nerves in the anterior stroma just below the epithelium. (D) A mid-stromal nerve trunk. Images B, C, D are $400 \times 400 \mu \mathrm{m}$. 


\section{Corneal degenerations and dystrophies}

It is important to differentiate between degenerations and dystrophies in the cornea because of their different causes, prognoses or treatments. A corneal degeneration is secondary to aging, inflammation, trauma, and systemic disease, or can be caused by abnormal deposition of collagen, calcium, iron or cholesterol. It is usually a non-hereditary, unilateral, asymmetric, progressive disorder, located peripherally on the cornea and may be associated with vascularization [47, 48]. A corneal dystrophy on the other hand, is defined as an inherited, bilateral, symmetric, progressive, non-inflammatory disorder, without relationship to environmental or systemic factors, occurring after birth [47, 49].

According to Weiss et al. [50] there are 26 different corneal dystrophies. The corneal dystrophies have earlier been subdivided dependent on their location in the cornea, which also reflects their clinical manifestation. A new classification system has recently been developed for corneal dystrophies, integrating phenotypic description, pathologic examination, and genetic analysis. This was developed by the International Committee for Classification of Corneal Dystrophies (IC3D). The anterior corneal dystrophies include dystrophies with changes located in the epithelium, epithelial basement membrane and Bowman's layer. The most prevalent anterior dystrophies include epithelial basement membrane dystrophy (EBMD), Recurrent corneal erosion syndrome, Meesmann corneal dystrophy, Reis-Bückler's corneal dystrophy and Thiel-Behnke corneal dystrophy. The anterior corneal dystrophies all exhibit signs of recurrent erosions and/or decreased visual acuity. A majority of the dystrophies are autosomal dominant. The development of genotypic analyses has enhanced the understanding of the corneal dystrophies. The main gene involved in anterior dystrophies is TGFBI with the gene locus 5q31. This combination is seen in EBMD, Reis-Bücklers corneal dystrophy, Lattice corneal dystrophy type 1 and Granular corneal dystrophy type 1 and 2 . There are many other known genes and loci related to dystrophies, but there are also a number of dystrophies with unknown genotype.

Abnormalities in different genes can cause a single phenotype, whereas different defects in a single gene can cause different phenotypes. Some disorders termed corneal dystrophies do not appear to have a genetic basis, for example EBMD does not seem to have a hereditary pattern in most patients. There are, however, numerous exceptions to the definition among the group of corneal dystrophies [50]. The anterior corneal dystrophies in the current classification scheme are listed below (modified after Weiss J et al., 2008) [50]. 
THE IC3D CLASSIFICATION

\section{Epithelial and Subepithelial Dystrophies}

1. Epithelial basement membrane dystrophy (EBMD)

2. Epithelial recurrent erosion dystrophy (ERED)

3. Subepithelial mucinous corneal dystrophy (SMCD)

4. Mutation in keratin genes: Meesmann corneal dystrophy (MECD)

5. Lisch epithelial corneal dystrophy (LECD)

6. Gelatinous drop-like corneal dystrophy (GDLD)

\section{Bowman Layer Dystrophies}

1. Reis-Bücklers corneal dystrophy (RBCD)

2. Thiel-Behnke corneal dystrophy (TBCD)

3. Grayson -Wilbrandt corneal dystrophy (GWCD)

\section{Epithelial basement membrane dystrophy}

Epithelial basement membrane dystrophy (EBMD), also known as Map-dotfingerprint, Cogan microcystic epithelial, or Anterior basement membrane dystrophy, is a common disorder of the anterior cornea that may affect at least $2 \%$ of the general population [4, 49]. It is present in adult life, and only rarely seen in children [50]. The main pathological feature of the disease is the abnormal attachment of epithelial basement membrane to the underlying Bowman's layer. This detachment gives rise to sheets of multi-laminar and rib-like extensions (folds) of basal laminar material, invading the more superficial epithelial cell layers (Figure 5) [50]. When the basal laminar folds block normal epithelial cell migration to the surface, the result is a degeneration of epithelial cells into cysts [51-56]. 


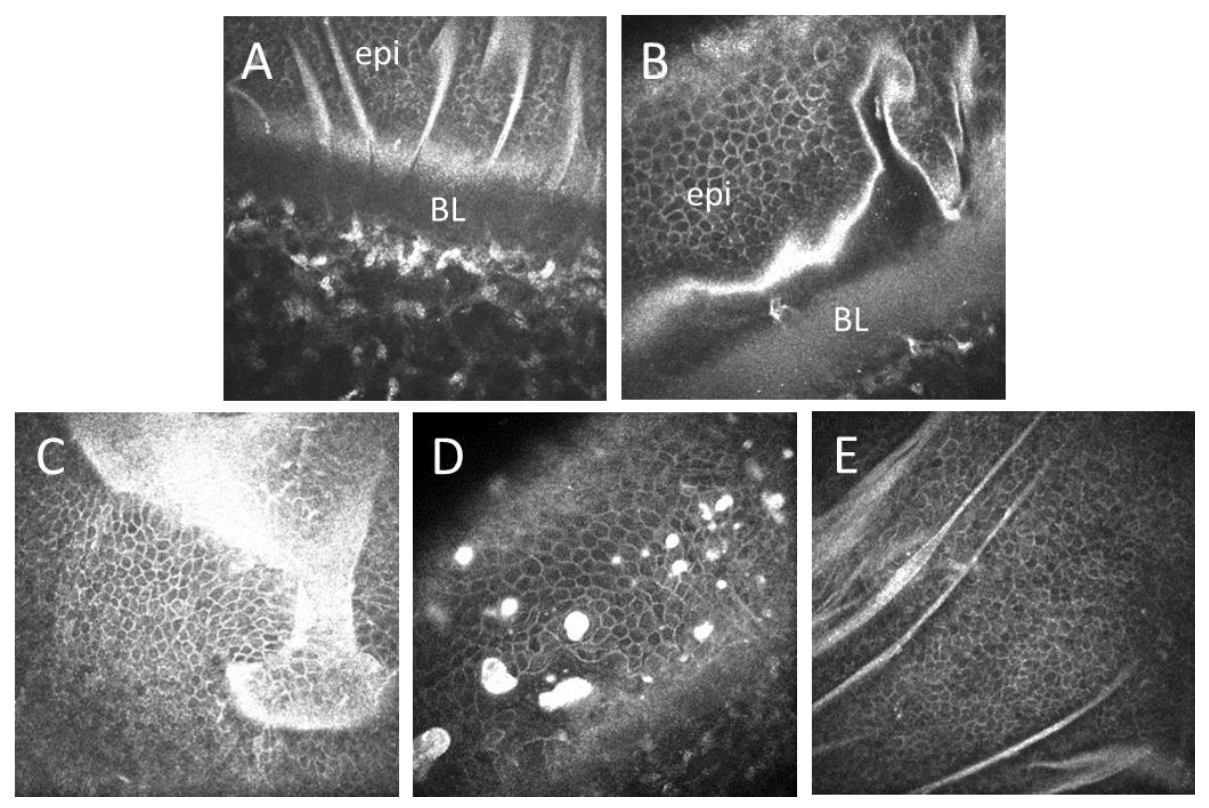

Figure 5. In vivo images of pathologic features of EBMD. (A, B) Oblique images from different subjects, depicting folding and separation of epithelial basement membrane from the underlying Bowman's layer. The basement membrane folds anteriorly towards more superficial epithelial cell layers. (C) En-face view of folded basement membrane appears as a map-like morphology in the epithelium. (D) Degeneration of epithelial cells into cysts or dot-like features. (E) Multiple, parallel folds give rise to a fingerprintlike morphology in the epithelium. Images $\mathrm{C}, \mathrm{E}$ are $400 \times 400 \mu \mathrm{m}$.

It is thought that the underlying defect in EBMD originates in the hemidesmosomes and anchoring fibrils, which form the important attachment complexes in the cell-to-stroma adhesion junction $[51,57]$. These attachment complexes normally ensure proper adhesion of epithelial basement membrane (and thereby epithelial cells) to the collagen of Bowman's layer or anterior stroma.

The epithelial lesions in EBMD can change in appearance, degree of severity, numbers and locations over a period of time. While the morphologic features of EBMD can be detected by routine biomicroscopic examination (Figure 6A), in many cases the features are difficult to observe biomicroscopically. Most cases have no inheritance documented, and many cases are considered to be degenerative or secondary to trauma. Familial cases have been reported and have been described as an autosomal dominant trait. The genetic locus 5q31 and the mutated gene TGFBI has been found in a minority of cases, but most patients present with no known familial inheritance $[50,58]$. Corneal dystrophies are by definition hereditary, therefore the term dystrophy is doubtful unless inheritance can be 
confirmed. Therefore EBMD should in the absence of a family history be more accurately classified as a corneal degenerative disorder.

While most cases of EBMD are asymptomatic [59], in about 10\%, symptoms of painful recurrent corneal erosions or degraded vision and unstable refraction are present [49] and require clinical attention. The current clinical method to diagnose EBMD is by confirming the symptoms of the patient with visible signs of dystrophy by slit lamp biomicroscopy (Figure 6A). The pathological features of the disease, however, can be difficult to find on routine examination and the help of a confocal microscope enhances the possibility to diagnose (Figure 6B). In most patients, symptoms are successfully managed by conservative treatment (such as lubricant ointments and therapeutic contact lenses), but about $10 \%$ of symptomatic patients [60] are unresponsive to conservative treatment measures and are considered for surgical intervention.

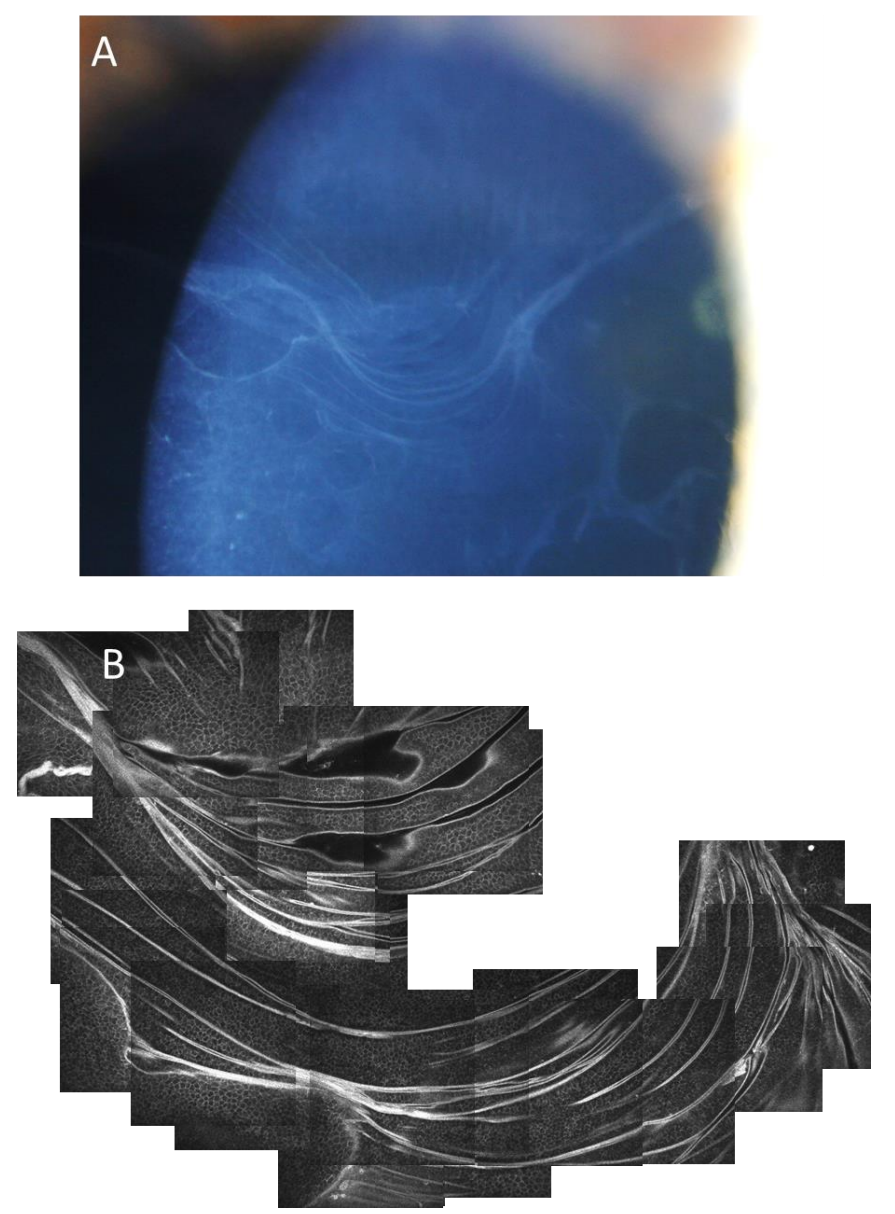

Figure 6. Features of EBMD observed clinically by slit lamp biomicroscopy (A), and the corresponding region as depicted by in vivo confocal microscopy (B). 


\section{Recurrent corneal erosions}

Erosions are associated with trauma, corneal dystrophies, or can be of idiopathic origin [61]. Most erosions occur in the early morning hours because of the eyelid motion over the ocular surface during sleep. The erosion is described as an event or attack, where the corneal epithelial cells erode, creating denuded areas on the corneal surface, causing symptoms of extreme ocular pain (due to the dense sensory innervation of the epithelium), photophobia, difficulty in opening the eyelids, irritation and redness of the eyes. The areas reepithelialise and most patients heal within 1-3 days with no specific treatment or by using simple conservative treatment [61]. In some patients (less than $1 \%$ of trauma patients [62]) the corneal erosion process recurs, and the epithelial cells do not attach properly and therefore slough again at a later time, causing new symptoms. The cornea may show subepithelial haze or epithelial micocysts between attacks. Attacks generally decline in frequency and intensity with age. Unlike EBMD, heredity of recurrent erosions has been documented in several large families in Sweden. The pattern and clinical/morphologic features of the recurrent erosions differ in different families, leading to the classification of variants as distinct corneal dystrophies [50]. In the less common Smolandiensis variant, central subepithelial kelloids will emerge, necessitating corneal transplantation in some patients [63]. The problem underlying the erosions is thought to originate from poor adhesion of basal epithelial cells to abnormal laminar material [50]. The pathophysiology of the abnormalities of epithelial adhesion is complex. Attachment complexes (containing for example hemidesmosomes, basal lamina, anchoring fibrils, laminin, fibrinonectin, Types IV and VII collagen), as well as basal epithelial cells, basement membrane, Bowman's layer and corneal stroma are involved $[61,64,65]$.

\section{Treatment of EBMD and RCE}

The treatment modalities are similar for RCE and EBMD. For recurrent erosion symptoms, the first line of conservative treatment is hyperosmotic agents, patching, and bandage contact lens. Concomitant ophthalmic diseases such as lid abnormalities, corneal inflammation, dry eye syndrome and blepharitis must also be treated if possible [61]. Tetracycline has been used for treating RCE symptoms by inhibiting the activity of matrix metalloproteinase-9, because matrixdegrading enzymes cause degradation of the epithelial adhesion complexes [66]. When medical management fails, surgical treatments are used. Debridement of loose epithelium is the oldest approach. This method is shallow and does not affect Bowman's layer and has been shown not to be more effective than pharmacological treatment alone regarding recurrences [64]. Superficial epithelial keratectomy using a blade to scrape the corneal surface and removing the underlying remaining abnormal basal lamina above the Bowman's layer, has shown good results, but it is hard to ensure that all abnormal basal lamina has been removed [67]. 
There are several treatment methods that affect Bowman's layer by disrupting this layer and making focal breaks in the stroma, causing scar tissue to anchor the epithelium to the underlying Bowman's layer and stroma (Table 2). Anterior stromal micro-puncture uses a needle [68] or a Nd:YAG laser [69] to puncture into Bowman's layer. Disadvantages of these methods are the difficulty in determining the depth of each puncture and the risk of scarring, which is why these methods are not considered safe in the visual axis. In patients with a pathologic basement membrane such as EBMD, stromal puncture operations have not been considered effective [69, 70]. Diamond burr polishing of the Bowman's layer (providing a smooth surface for new epithelial growth and creating stronger adhesion complexes by stimulating the expression of extracellular matrix proteins) has shown good results regarding recurrent erosions in some studies [70, 71]. All of the above treatments are easy office procedures that are less expensive then PTK, but they all lack the repeatability and preciseness of treatment depth compared to the excimer laser.

In recent years, excimer laser phototherapeutic keratectomy (PTK) has become an increasingly used surgical option for the treatment of EBMD, due to successful resolution of symptoms both visual and RCE related, as documented in a number of studies [60, 70, 72-81]. An excimer laser generates $193 \mathrm{~nm}$ wavelength ultraviolet radiation using the energy source of an unstable argon-flouride gas compound. The focused energy generated from the laser disrupts the molecular bonds in the corneal tissue (ablation). Each laser pulse ablates the same exact amount of corneal tissue making the surgery very precise. PTK is an anterior approach removing all corneal tissue to a predetermined, fixed depth, and allows the removal of superficial corneal opacities and surface irregularities [82]. While the majority of PTK treatments are successful, postoperative recurrence of symptoms has been reported, and the reasons for recurrence remain unclear $[60,70$, 74-76, 83-84].

\begin{tabular}{||l|l|l|l|l||}
\hline Treatment & $\begin{array}{l}\text { Nr of } \\
\text { Eyes }\end{array}$ & $\begin{array}{l}\text { FUT } \\
\text { (months) }\end{array}$ & $\begin{array}{l}\text { Success } \\
\text { rate }\end{array}$ & Reference \\
\hline \hline Mechanical abrasion & 15 & 17 & $93 \%$ & {$[67]$} \\
\hline \multirow{3}{*}{ Diamond burr } & 27 & 7 & $89 \%$ & {$[70]$} \\
\hline \multirow{3}{*}{ PTK } & 31 & $6-23$ & $84 \%$ & {$[71]$} \\
\hline & 30 & 30 & $90 \%$ & {$[74]$} \\
\cline { 2 - 5 } & 15 & 58 & $100 \%$ & {$[79]$} \\
\cline { 2 - 5 } & 36 & 12 & $86 \%$ & {$[60]$} \\
\cline { 2 - 5 } & 15 & 18 & $73 \%$ & {$[70]$} \\
\hline
\end{tabular}

Table 2. Historical treatment modality data from the largest studies showing success rate of alleviating recurrent erosion symptoms in EBMD eyes. FUT= Follow up time. 


\section{Corneal wound healing and regeneration}

To heal an epithelial wound, the epithelium initiates migration of basal epithelial cells from the wound edge. The migrating and proliferating epithelial cells will cover the defect and re-establish the cornea's outer barrier. Epithelial wound healing can be broadly described as composing three steps [85]. In the first step, pre-existing cells flatten and slide to cover the corneal wound. Hemidesmosomes detach from migrating cells, and the leading cells pull the epithelial sheet as they migrate, covering the wound with a thin layer of cells. In the second step, mitosis and migration from the limbal stem cells provides new basal cells, filling the remaining defect within 24-72 hours. In the final step, the epithelium is remodelled and normal cytoarchitecture and function is re-established by formation of hemidesmosomes and adhesion complexes which can take up to 12 months depending on whether the basement membrane was involved in the injury [15, 85-87]. The basement membrane is regenerated by the advancing cell front and facilitates the migration and later adhesion [12]. Directly after debridement of the epithelium, the underlying keratocytes in the anterior stroma undergo apoptosis [88]. The keratocyte free area repopulates in a few days [89]. The keratocytes then undergo proliferation, migration and fibroblastic transformation to produce new collagen fibrils and extracellular matrix components [90-93].

\section{Nerve regeneration}

Nerves are severed by various surgical interventions. Regeneration of nerves can vary, depending on the species, location, and nature of the injury. After corneal transplantation in rabbits, regenerated nerves have been seen to cross into the graft from the periphery after 3-5 weeks, and after 3-7 months mature nerve fibres were found throughout the whole graft. Full ocular surface touch sensitivity could be demonstrated after 4-7 weeks in young animals and 10-13 weeks in adult animals [94].

Nerve regeneration in humans after photorefractive keratectomy (PRK) is characterized by sprouting nerve fibres at the margin of the wound in the anterior stroma 1-2 months postoperatively. At 3-months, subbasal nerve fibres have been observed in the central cornea and after 5-8 months the subbasal plexus appears fully regenerated. Subbasal nerve density has been reported to return to preoperative levels after 5 months to 2 years. In some cases even 5 years post-PRK, subnormal density of subbasal nerve bundles have been observed [23], and regenerated nerve patterns have been noted as abnormal $[45,95,96]$. After penetrating corneal transplantation, nerves have been detected in the central stroma 6 months postoperatively and nerves at the level of Bowman's layer at 12 months [97]. Reinnervation of the central basal epithelium was observed after 2 years postoperatively [98]. Long-term follow up reveals that the architecture and density of nerves in the transplanted cornea may not return to normal $[99,100]$. Sensation 
in the centre of the transplanted cornea does not fully return until years or decades after transplantation [101].

\section{In vivo confocal microscopy}

In 1957, Marvin Minsky invented the principle of confocal microscopy [102], but it was not until 1990 that Cavanagh et al. published the first in vivo images of the human cornea using the confocal technique [103]. In vivo confocal microscopy (IVCM) is a direct, non-invasive imaging method causing no damage to the eye. The confocal microscope uses serial optical sectioning of intact living tissue, with a minimum of sample preparation. It enables in vivo imaging of the inner structures of the cornea without the use of dyes, in a non-selective manner. The clear advantage is that the tissue can be examined in vivo in its native state, with all cell types present.

There are three classes of in vivo confocal microscopes. All utilize the same basic principle to enable optical sectioning in the human cornea in vivo. 1 . The tandem scanning confocal microscope (TSCM) is based on a point illumination and detection, with a spinning disc used to create a two-dimensional image. 2. The slit scanning confocal microscope (SSCM) uses multiple points of illumination as a slit to scan a focal plane, thereby reducing scanning time. A lower intensity, white light source can be used and the contrast is more enhanced compared to the TSCM. 3. The laser scanning confocal microscope (LSCM) uses a coherent, high intensity light source (laser beam) for point scanning, thereby providing a greater contrast and better depth resolution than both TSCM and SSCM [104, 105].

Confocal microscopy is a technique for obtaining high-resolution in-focus images from selected depths, a process known as optical sectioning. A conventional microscope illuminates the entire thickness of the sample and collects scattered light from the entire thickness to form an image. A confocal microscope illuminates and collects light from only a thin plane or section within the sample. Images are acquired point by point by means of a focused light beam, scanning mirrors, and computer reconstruction that results in two- and three-dimensional reconstructions of topologically complex objects.

The principle of the LSCM is depicted in Figure 7. In a LSCM, a laser beam passes through a light source aperture and is then focused by an objective lens into a small focal volume within or on the surface of a specimen. Scattered and reflected laser light as well as any fluorescent light from the illuminated spot is then re-collected by the objective lens. After passing a pinhole that blocks the scattered light from outside the plane of illumination, the light intensity is detected by a photodetection device, transforming the light signal into an electrical one (pixel) that is recorded by a computer. As the laser spot scans over the plane of interest, an entire image is obtained pixel by pixel and line by line, where the 
brightness of a resulting image pixel corresponds to the relative intensity of detected light [102].
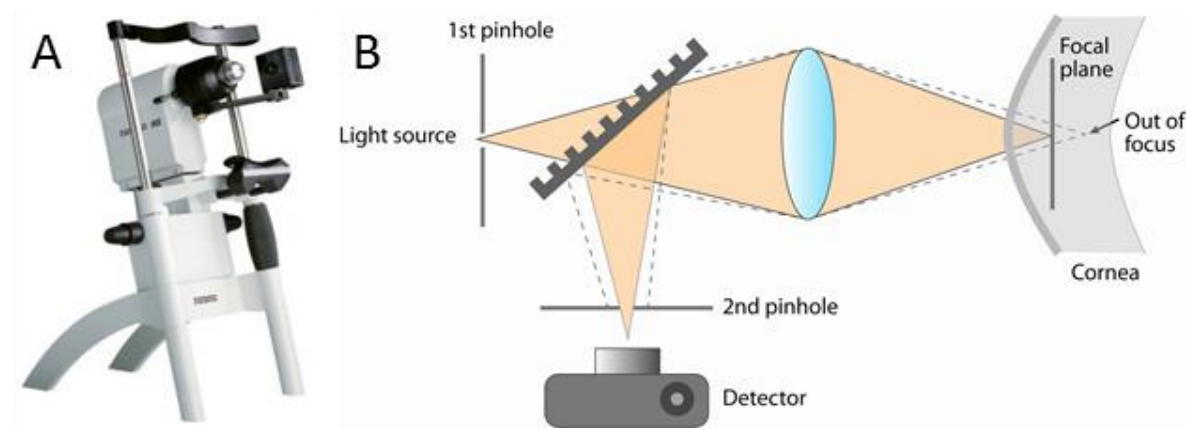

Figure 7: (A) Laser scanning in vivo confocal microscope used for corneal examination (Heidelberg Retinal Tomograph 3 with Rostock Corneal Module, Heidelberg Engineering). (B) Optical principle of confocal microscopy. Light passes through a pinhole and is focused through a lens on a focal plane in the cornea. Returning light scattered from corneal structures again passes through the lens and is diverted by the beam splitter to a second pinhole that blocks all out of focus scattered light before reaching the detector.

The cornea is a model tissue for microscopy, because of its transparency, thin structure and anatomical location. The cornea transmits visible light with very little absorption, while the cellular features of interest within the cornea often strongly scatter light, resulting in the possibility of obtaining high contrast images by optical techniques [106].

The use of IVCM in scientific research in ophthalmology is extensive both in humans [104, 105] and in preclinical animal research [107-111]. IVCM has also been used for clinical diagnosis of pathology of the cornea and as a screening/monitoring tool for patients undergoing treatment [112-115]. Other applications are distinguishing different inflammatory cell subtypes in corneal inflammation, and feature recognition for diagnosis, such as acanthamoeba and fungal keratitis. IVCM can also be used for investigating keratocyte apoptosis, detection of the limbal epithelial stem cell niche, and for nerve and cell analysis and quantification [106]. 


\section{IVCM appearance of the normal human cornea}

A summary of the microscopic appearance and features of the normal human cornea at various depths is presented in Figure 8. The different depths within the cornea are imaged by adjusting the axial alignment to select a given focal depth in the cornea.

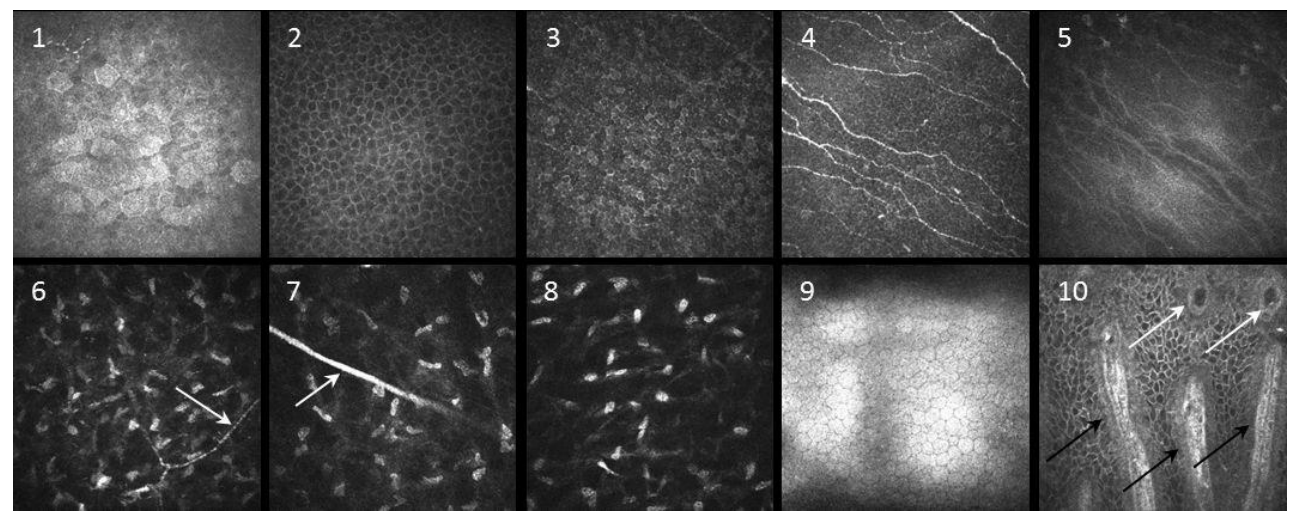

Figure 8. IVCM appearance of the corneal layers in a normal human subject. Images represent (1) superficial epithelium, (2) epithelial wing cell layer, (3) basal epithelium, (4) subbasal nerves, (5) Bowman's layer, (6) anterior stroma with nerve segment (arrow), (7) mid stroma with nerve trunk (arrow), (8) posterior stroma, (9) endothelium, and (10) limbal Palisades of Vogt (black arrows).

In addition, the microscope can be used in an 'oblique' mode, whereby the microscope objective lens contacts the cornea at an oblique angle, thereby providing a cross sectional representation of the cornea (Figure 9). Because of the oblique angle, however, accurate distance measurements are no longer possible. 


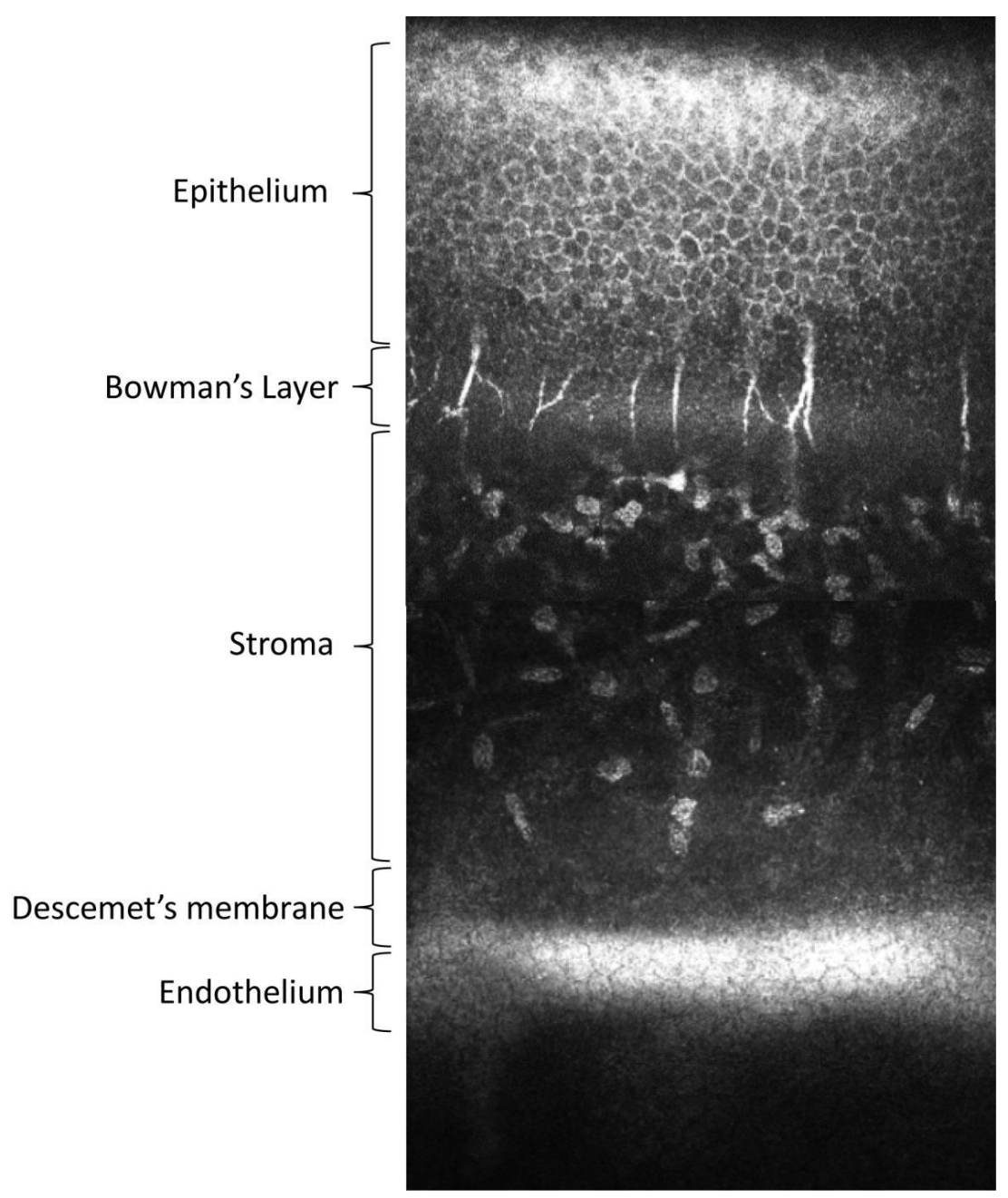

Figure 9. Live histological cross section representation of a normal cornea by IVCM, with the major anatomic layers indicated.

\section{IVCM of the subbasal nerve plexus}

The subbasal nerve plexus has been a popular anatomic location for nerve assessment by IVCM, because of its ease of visualization and the location of a high density of nerves in a single plane. Quantitative nerve analysis has been performed by a number of investigators $[25,43,45,46]$ and in the case of the subbasal nerve plexus, reporting of nerve density has followed an accepted convention. Nerve density values determined from laser scanning confocal instruments can therefore be compared. Nerve density is reported in terms of total nerve length per unit area of the central corneal subbasal nerve plexus. In practice, a 
single $400 \times 400 \mu \mathrm{m}$ field of view image obtained from the central cornea is chosen, typically with the greatest number of visible subbasal nerves. Nerves in the image are then semi-automatically traced by the aid of tracing software [43, 108] to determine total nerve length, which is then divided by the area in the field of view, to determine nerve density in $\mu \mathrm{m} / \mathrm{mm}^{2}$. The subbasal nerve density in humans changes with age [26], but in general the accepted value for the average subbasal nerve density by IVCM is about $20000 \mu \mathrm{m} / \mathrm{mm}^{2}$ in the central cornea $[25,26,45]$.

\section{Cell quantification techniques}

The cornea contains many different types of cells suitable for quantification using IVCM. The epithelium consists of superficial, wing and basal cells, the stroma contains keratocytes and the endothelium consists of endothelial cells. Counting of cells can for instance provide information about pre- and postoperative cell densities or an inflammatory response after injury. The fine axial resolution of IVCM requires specification of the exact depth of the layer to be quantified. The resulting densities are specified as cells $/ \mathrm{mm}^{2}$. Once depth is specified, the desired region of interest must be chosen, as it is often impractical to quantify all cells in an image, and desirable to exclude edge artefacts. Image processing techniques are then applied to the region of interest to enhance cell boundaries and facilitate manual cell counting [106]. 


\section{AIMS OF THE PRESENT STUDY}

\section{General aim:}

To improve the understanding and management of EBMD by investigating the diagnosis and treatment of EBMD and its relationship to Bowman's layer.

\section{Specific Aims:}

- To examine the role of Bowman's layer in corneal healing after excimer laser phototherapeutic keratectomy (I)

- To evaluate the outcome of phototherapeutic keratectomy treatment of epithelial basement membrane dystrophy in relation to time and various treatment parameters (II)

- To determine an accurate value for Bowman's layer thickness in vivo in the human cornea (III),(IV)

- Examine how EBMD corneas differ from healthy normal corneas microscopically (V)

- Examine how PTK treatment changes the cell and subbasal nerve density in EBMD eyes (V)

- Investigate if a fully automated cell analysis technique can be used to replace manual assessment of epithelial cells in IVCM images (V) 


\section{MATERIALS \& METHODS}

All subjects were treated in accordance with the tenets of the Declaration of Helsinki, and with approvals from the local Human Ethics Committee at Linköping University. Signed, written informed consent was obtained from all subjects.

\section{Study design and subject groups}

Study I: A cohort of 13 patients was recruited. All patients underwent excimer laser PTK in one eye, to treat recurrent corneal erosions (RCE). Patients were divided into two roughly equal groups, depending on their etiology. In seven eyes, RCE was secondary to EBMD, while in the remaining six eyes, RCE was traumatic or of idiopathic origin. The study was a longitudinal, prospective, cohort study, with all patients examined preoperatively and at 4 and 8 months postoperatively.

Study II, V: All patients with EBMD who underwent PTK in a single clinic between the years 2001 and 2008 were investigated in order to evaluate the outcome and to examine clinical and morphologic signs of recurrent dystrophy. This study included 52 eyes from 39 patients. 18 eyes were treated for recurrent erosions, 26 eyes for reduced vision, and 8 eyes were treated for both symptoms. The study was a cross sectional, cohort study.

Study III: 17 consecutive patients were recruited prior to penetrating keratoplasty (PK). Indications for PK included endothelial decompensation, keratoconus, and keloids with an uneven corneal surface. The study intended to determine an accurate value for BL thickness in vivo. Additionally, a group of 20 healthy volunteers was recruited for comparison. The study was a controlled, prospective, observational study.

Study IV: 82 healthy volunteers, divided in roughly equal numbers of participants into 4 age groups (15-30y, 31-45y, 46-60y, 61+y), were recruited in this prospective, observational study to determine the thickness of BL in vivo in a normal healthy population.

Study V: Two subject groups were examined for this study. The first group consisted of 39 EBMD patients treated by PTK. To investigate the characteristics of the cornea in untreated eyes with EBMD, examination data from 24 nonoperated, asymptomatic fellow eyes were also included. The second group was a control group of 40 healthy volunteers. The study was a cross sectional study intending to investigate the effect of PTK treatment on corneal cell and nerve density in EBMD. 


\section{Excimer laser phototherapeutic keratectomy (Study I, II, V)}

The patient groups who underwent PTK in studies I, II, and V were all operated at the Department of Ophthalmology, Linköping University Hospital, by one of three surgeons during the years 2001-2008. The surgical procedure was as follows. After application of topical anaesthesia, the corneal epithelium was removed mechanically with a no.57 Beaver blade (all patients in Study I) when the surface was uneven or as in Study II by laser plano ablation (set to a fixed depth of $55 \mu \mathrm{m}$ ) when the corneal surface was smooth similar to the method previously reported [75]. The treatment zone was typically $7.0 \mathrm{~mm}$ in diameter in the central area of the cornea in all eyes. The Technolas 217 excimer laser system (Bausch $\&$ Lomb, Munich, Germany) was used for all treatments. The laser system is an argon-fluoride $193 \mathrm{~nm}$ laser with a repetition rate of $50 \mathrm{~Hz}$ and a fluence of $120 \mathrm{~mJ} / \mathrm{cm}^{2}$.

In Study I, following epithelial removal, the ablation depth was set to $15 \mu \mathrm{m}$ for complete removal of $\mathrm{BL}$ in EBMD cases and $7 \mu \mathrm{m}$ for removal of half the thickness of BL in non-dystrophic RCE cases. In Studies II and V, about half of the patients were treated with a $15 \mu \mathrm{m}$ ablation depth, one-third were treated with less than $15 \mu \mathrm{m}$ ablation, and about $10 \%$ were treated with greater than $15 \mu \mathrm{m}$ ablation. The standard protocol in the clinic today for treatment of EBMD patients is a $15 \mu \mathrm{m}$ ablation depth after epithelial removal. After surgery, patients received long acting local anesthesia Cincain $^{\circledR}$ and antibiotic eye ointments before applying an eye patch. During the first postoperative 24 hours, anesthetic ointment Cincain $^{\circledR}$ was also applied and oral analgesics were given for pain relief.

\section{Tissue preparation (Study III)}

To enable a detailed study of Bowman's layer by light and electron microscopy, corneal buttons were obtained from patients who underwent penetrating keratoplasty at the Linköping University Hospital. Samples of the central part of the excised corneal buttons were taken using a $2 \mathrm{~mm}$ biopsy punch and stored in $2 \%$ glutaraldehyde solution for no more than one week. The samples were then imbedded in resin, and $4 \mu \mathrm{m}$ thick sections were made and stained with toluidine blue dye for light microscopy. Ultrathin sections were then prepared for TEM (60nm sections on Cu150 mesh grids). Post staining was done with lead citrate and uranyl acetate. 


\section{Light microscopy (Study III)}

BL thickness in tissue sections by light microscopy (LM) was determined using a light microscope with a $100 \times 1.30 \mathrm{NA}$ oil immersion objective lens. Four to twelve separate sections for each central cornea were imaged in the light microscope, and three measurements per section were taken. Distances were calibrated by imaging a standard etched glass ruler microscope slide and image processing software [116] was used to take measurements. Each patient's reported central BL thickness value was a mean of the measurements made by two independent observers, and each observer's value was the mean of all measurements from the various sections.

\section{Transmission electron microscopy (Study III)}

Ultrastructural analysis was performed using a transmission electron microscope (TEM) at $80 \mathrm{kV}$ (JEM-1230; JEOL, Tokyo, Japan). In particular, the collagen structure and anterior-posterior borders of BL were examined.

\section{Optical coherence tomography (Study IV)}

To determine central corneal thickness in vivo by a standard, reproducible method, anterior segment optical coherence tomography (ASOCT; Visante ${ }^{\circledR}$, Carl Zeiss Meditec, Jena, Germany) was used. The principle of OCT involves two coherent paths of light: a sample path passing into the eye and a reference path. By scanning a mirror in the reference path, a reflectivity profile of the sample can be obtained. This reflectivity profile is called an A-scan. Multiple A-scan images can be transformed into visual representations for analysis [117].

All participants underwent a global high resolution pachymetry scan bilaterally prior to IVCM examination. Central corneal thickness was taken as the mean value in the central $2 \mathrm{~mm}$ diameter zone as determined by the ASOCT software.

\section{In vivo confocal microscopy (Study I -V)}

Laser scanning IVCM (Heidelberg Retinal Tomograph 3 with Rostock Corneal Module, HRT3-RCM, 670nm wavelength diode laser, Heidelberg Engineering, Germany) was used in all studies. The microscope was equipped with a $63 \times 0.95$ NA water immersion objective (Zeiss, Oberkochen, Germany). The microscope has distinct modes of scanning. In the present studies, two scanning modes were used: the sequence scan and the volume scan. In the sequence scan mode, 100 images are acquired at a selectable image acquisition rate. Typically 8 images/second were acquired. During acquisition, the operator can adjust the depth in the cornea and/or the lateral location on the cornea, in order to sample different areas of the cornea. In the volume scan mode, the sampling location on the cor- 
nea is fixed laterally, while depth is automatically scanned by an internal motor, to obtain 40 images spanning a thickness of $80 \mu \mathrm{m}$. Regardless of scanning mode, the field of view and therefore the size of a single IVCM image is limited to $400 \times 400 \mu \mathrm{m}$. By manual adjustment of the field of view, a larger area of the cornea can be imaged.

Study I: From each IVCM examination, six en face confocal images from the central cornea were acquired for quantitative analysis. Images were selected from the anterior cornea, the part of the cornea which was exposed to the laser during PTK treatment. Images represented the superficial epithelium, epithelial wing cells, basal epithelium, subbasal nerves, and two images of anterior stromal keratocytes. BL was identified in IVCM images on the basis of its acellularity, slightly increased reflectivity relative to the anterior stromal extracellular matrix, and the visibility of nerve fiber bundles (in a Schwann cell sheath) underlying BL.

Study II: For each cornea, images were acquired at 8 frames/second while a region of approximately $5 \mathrm{~mm}$ in diameter of the central cornea was scanned manually. Depth was adjusted to acquire images of epithelial wing cells, the subbasal nerve plexus, and BL. Images were recorded during scanning, and a typical examination consisted of 1000 images.

Study III: To enable an estimation of BL thickness in vivo preoperatively, five to seven separate image sequences of the central cornea were taken by IVCM in sequence scan mode $(2-7 \mu \mathrm{m}$ axial spacing) with images acquired at 8 frames/second while the focal plane was adjusted manually from the corneal surface through the epithelium, BL, and into the anterior stroma. Based on light microscopy findings and the possibility to obtain a finer axial spacing of images using the IVCM volume scan mode ( $2 \mu \mathrm{m}$ axial spacing between images), the method for measuring BL in vivo was revised to improve accuracy. The revised method was validated in an in vivo study of 20 healthy volunteers.

Study IV: For accurate quantification of BL thickness, subjects were examined bilaterally and for each examined eye, up to 10 confocal scans were obtained. The volume scan mode was initiated when a central corneal wing cell layer was visible in the real-time image display, and the scan automatically terminated in the anterior stroma. After each scan, the lateral positioning of the microscope objective was adjusted to image a different central location, and a scan was repeated. Typically several central corneal locations were scanned for each eye. Because the volume scans resulted in more closely spaced images axially (separated by approximately $2 \mu \mathrm{m}$ in depth), the majority of scans taken were volume scans. 
Study V: The central region of the cornea in all subjects was examined by IVCM, using the procedure described in Studies I and II. In the EBMD and healthy volunteer groups, six en-face confocal images from each central cornea were selected for quantitative analysis. The first three images contained epithelial wing cells approximately $20-25 \mu \mathrm{m}$ posterior to the corneal surface. The remaining three images were of nerve fibre bundles of the subbasal nerve plexus, located immediately posterior to the epithelium. The selection procedure was chosen to reflect the general epithelial cell and nerve density in EBMD, taking into account both obviously affected regions and regions without visible pathology.

\section{Image processing and manual quantitative analysis (Study I-V)}

Study I: A total of 234 images were selected for analysis (13 patients, three examinations/patient, and six images/examination). All images were randomized before analysis to mask observers to the patient, depth of ablation, and time of examination. ImageJ image-processing software [116] was used to superimpose a $200 \times 100 \mu \mathrm{m}$ (width $\mathrm{x}$ height) rectangle onto each image of superficial, wing, and basal epithelial cells, while for images of subepithelial keratocytes, a similar procedure was used, but with a $250 \times 250 \mu \mathrm{m}$ square placed in the geometric centre of the image. Within each selected region, filtering was applied. Images with subbasal nerves were not preprocessed in any way before analysis. Cells and nerves within $100 \%$ of the images were quantified by two independent observers. Cells were counted manually by each observer with the assistance of point and click cell marking and counting software [116]. Subbasal nerves were traced by a semi-automated method using nerve tracing software [118]. The total number of cells or total nerve length (in pixels) per image was recorded by both observers separately. Cell density (cells $\left./ \mathrm{mm}^{2}\right)$ and nerve density $\left(\mu \mathrm{m} / \mathrm{mm}^{2}\right)$ were calculated for each image, and the images were unmasked to enable grouping according to cell type. The mean cell or nerve density determined by the two observers was taken as the cell or nerve density for that image.

Study II: After bilateral confocal image acquisition for all patients in this study, images were randomized and examined for characteristic features of EBMD: maps, dots, or fingerprint lines, based on previously published in vivo classification criteria [119]. In addition, in corneas where map, dot, or fingerprint features were present, a 3-point grading scale was used to classify the severity of EBMD morphologic features as observed by IVCM $(1=$ mild, $2=$ intermediate, $3=$ severe $)$. The grading of morphologic features was undertaken by 2 independent, experienced observers masked to the patient data. Images also were analyzed for the 
presence or partial presence of BL. In cases where basal epithelial cells and anterior stromal keratocyte nuclei were visible in the same en face confocal image frame, BL was deemed to be absent.

Study III: Two independent observers performed each measurement. BL thickness was measured in vivo as follows.

Method 1: The anterior surface of BL was considered as the most posterior infocus epithelial layer without haze. The posterior surface of BL was considered as the most anterior layer of keratocytes that were in focus without haze present. Method 2: The interpretation of the borders was revised, such that the top of BL was considered as the most anterior epithelial layer with haze (slight haze and subbasal nerves visible). The bottom of BL was considered as the most anterior layer of stroma that showed some haze present and had visible indistinct keratocytes (Fig. 10). For Method 2, each subject's reported BL thickness was the mean of the values reported by the two observers, and each observer's value was the mean of five to seven distinct image sequence measurements.

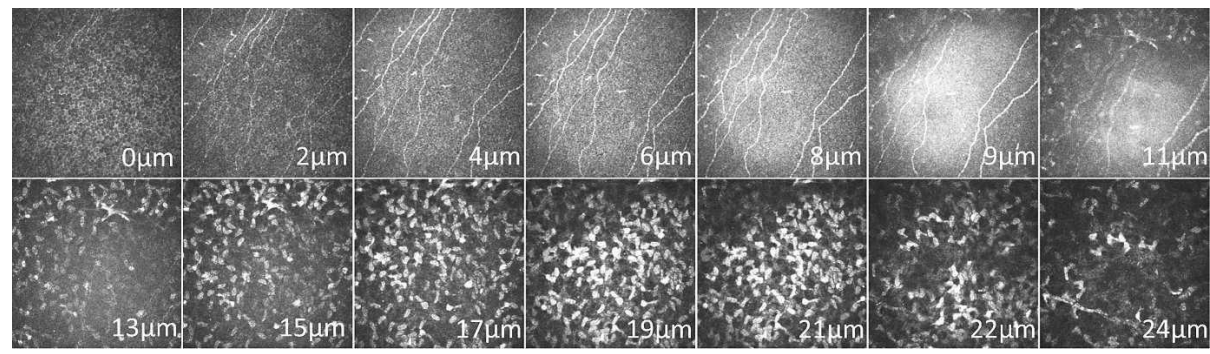

Figure 10: Series of consecutive image frames obtained by laser scanning IVCM in a healthy volunteer, using the volume scan method. The series is used to illustrate two methods of in vivo measurement of BL thickness. Method 1: Measurement starts at the most posterior in-focus epithelial layer without haze $(0 \mu \mathrm{m})$ and stops at the most anterior layer where central keratocytes are in focus without haze $(15 \mu \mathrm{m})$. BL thickness by this method is $15 \mu \mathrm{m}$. Method 2: Measurement starts at the most posterior epithelial layer $(2 \mu \mathrm{m})$ with haze. The measurement stops at the most anterior stromal layer with haze and where indistinct keratocytes are visible $(13 \mu \mathrm{m})$. BL thickness by this method is $11 \mu \mathrm{m}$. All images are 400x400 $\mu \mathrm{m}$.

Study IV: Central corneal thickness was measured using anterior segment optical coherence tomography (Visante ${ }^{\circledR}$, Carl Zeiss Meditec, Jena, Germany). All participants underwent a global high resolution pachymetry scan bilaterally prior to IVCM examination. IVCM scans were used to determine BL thickness based on the method outlined in Study III, but with the following adjustments. For each sequence of images, only the morphologic features in a small part of the image frame were considered, to further avoid the influence of image obliqueness and pressure-induced artefacts. The same part of the image was observed in succes- 
sive image frames to identify the features defining the anterior and posterior limits of Bowman's layer. The image numbers corresponding to the anterior and posterior BL limits were recorded, and only later was the image depth unmasked. BL thickness was determined independently by two trained observers. For each eye, a mean BL thickness was calculated from measurements of thickness in approximately 4 different regions in the central cornea.

In the 82 subjects, BL thickness was determined at a mean of 3.9 different central corneal locations in the right eye and at a mean of 3.7 in the left eye. For each eye, a single mean central BL thickness was determined by averaging the values from the different locations. The mean value for each eye obtained by each observer was compared.

Study V: All images were randomized prior to analysis to mask observers to the subject (healthy or dystrophy) and eye (operated or non-operated). After image randomization, ImageJ software [116] was used for analysis in the same manner as in Study I.

\section{Automated cell counting (Study V)}

To investigate a more rapid and objective method for cell analysis, a fully automated cell counting procedure was developed in the ImageJ platform as follows. A rectangular region of interest was first placed on each image, and the image was background-subtracted and bandpass filtered in a manner identical to the manual procedure (Figure 11). The image was then cropped to the region of interest, and thresholding was applied using the auto-default setting. The image was then converted to black/white ('Make Binary' function), and the 'Watershed' function was used to automatically add boundaries where needed, in order to separate cells appearing to be adjoined.

Wing cells in pre-processed images were automatically counted using the 'Analyze Particles' function in ImageJ. A threshold range for cell size was also set. The wing cell density for a given eye was taken as the mean value from automated analysis of the three individual image frames from that eye. 

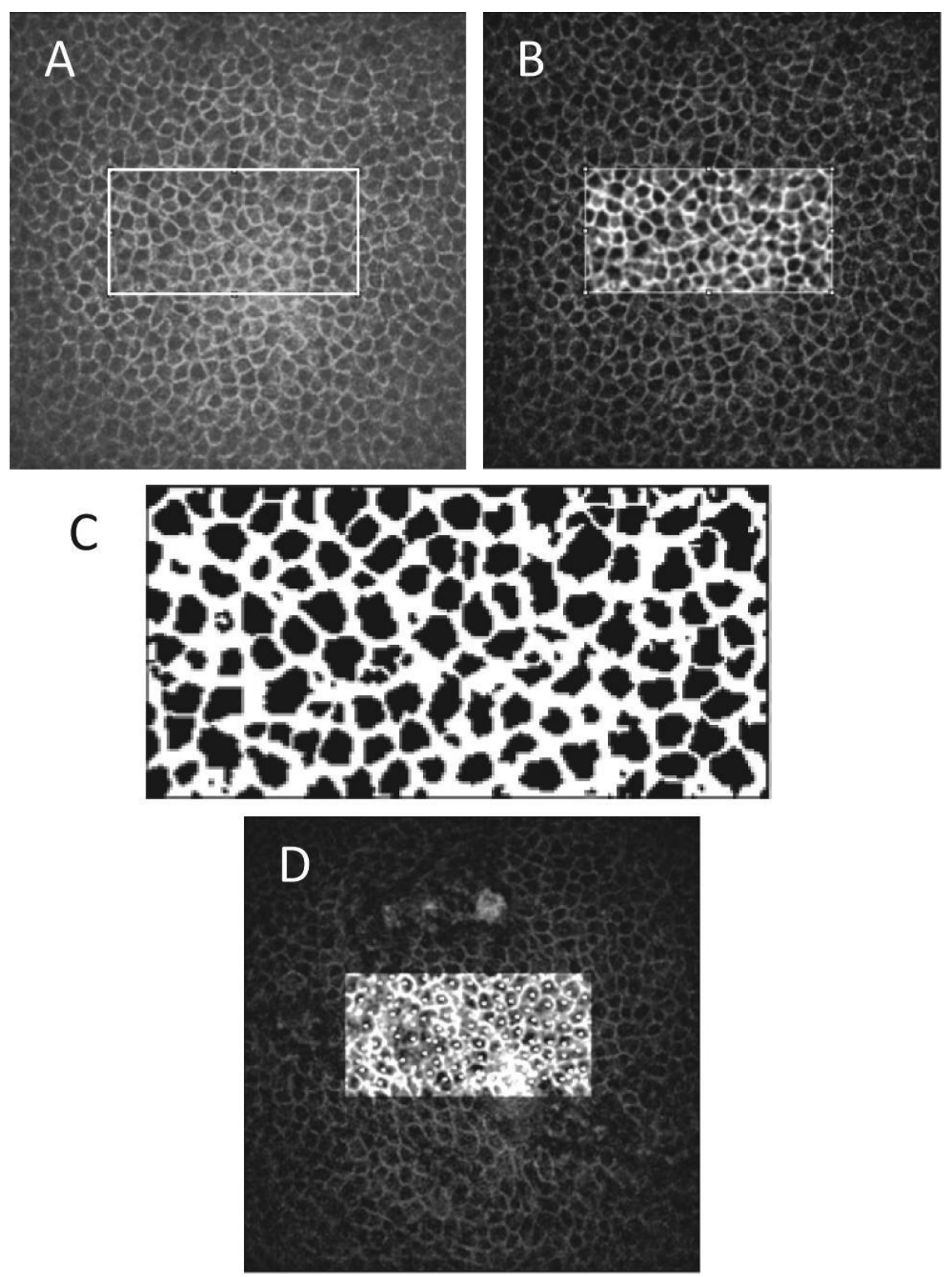

Figure 11. Example of image pre-processing in fully automated and manual cell analysis. (A) A region of interest (rectangle) is overlaid on a raw IVCM image of wing cells. (B) Image after background subtraction and bandpass filtering. (C) The region of interest is cropped, automatic thresholding is applied, the image is binarized and the watershed function has been applied to separate adjoined regions into individual cells. (D) For manual cell analysis, the filtered image is used for manually marking individual cells using software [116] 


\section{STATISTICAL ANALYSIS}

Statistical testing was performed with commercial software (SigmaStat 3.5; Systat Software Inc., Chicago, IL) in all studies. Statistics were also analyzed using commercial software (Stata software version 11.0, StataCorp, College Station, TX) in Study II. In all studies, statistical tests were two-tailed, and a P value of less than 0.05 was considered statistically significant, with the exception of posthoc multiple comparisons, where the critical $\mathrm{P}$ value was adjusted accordingly (Bonferroni correction). In all cases, the Kolmogorov-Smirnov procedure was used to test normality, and thereby determine the appropriate statistical test to use.

Study I: In this study, epithelial cell, keratocyte, and nerve densities were grouped according to time and PTK ablation depth. Time-dependent comparisons were performed on all study patients as a single group, and within two subgroups of patients (full and partial BL removal). For time-dependent comparisons, repeated measures ANOVA was used, with significant differences isolated post hoc with the Student- Newman-Keuls method. Where data was normally distributed but with unequal variances, multiple paired t-tests were used. In addition, the two patient subgroups with differing ablation depth were compared at a fixed time using the independent t-test or the Mann-Whitney rank sum test.

Study II: The cross sectional nature of this study, with variable follow-up times, required a more complex statistical analysis. Moreover, the inclusion of bilateral data from 13 patients required statistical correction for potential inter-eye correlation within a subject $[120,121]$. To account for variable follow-up time and inter-eye correlation, an exact logistic regression analysis was performed. Recurrence (of any form, and morphologic only) was treated as the dependent variable, while bilaterality and follow-up time were conditional variables, and age, gender, ablation depth, epithelial removal method, and presence of BL were independent variables. Visual outcomes were reported using a single eye per patient, and the relationship of visual acuity and refractive change to follow-up time was investigated by Pearson correlation with time as an independent variable.

Study III: In this study the Bland-Altman method was used to compare interobserver differences in BL thickness using the 95\% limits of Agreement (95\% LOA) [122]. Comparison of BL thickness between LM and IVCM methods was performed using the paired t-test and Pearson correlation. For the in vivo data, two methods of analysis (Method 1 and Method 2) were compared using the 
paired t-test and Pearson correlation. Additionally, correlations were examined by regression analysis, using the built-in linear regression function in a spreadsheet (Excel 2007; Microsoft Inc., Redmond, WA).

Study IV: Two independent observers measured BL thickness using IVCM image data obtained from a large group of healthy subjects. The Bland-Altman method [122] was used to compare differences in BL thickness measurements between the two independent observers, and differences were reported as the 95\% LOA. Inter-observer correlation of BL thickness and correlation of central corneal thickness and BL thickness with eye and age was examined by the Pearson correlation test. Difference in BL thickness across several defined age categories was tested with one-way ANOVA and the t-test, while differences in corneal thickness or BL thickness in male and female subjects was investigated using the t-test.

Study V: To test for differences in cell and nerve density between observers, among subject groups, or between cell analysis methods, a two-way analysis of variance (ANOVA) was applied using a general linear model. Cell and nerve density values were the dependent variables while observer (or analysis method) and subject group were treated as independent variables. The Holm-Sidak method was used to isolate significant differences. To test for correlations between observers or counting methods, the Pearson product moment correlation test was used. 


\section{RESULTS}

Study I: The role of Bowman's layer in corneal regeneration after phototherapeutic keratectomy. Within the cohort of 13 eyes with RCE and EBMD treated with PTK, mean BSCVA was 1.0 (20/20 Snellen equivalent; range, 1.0 $1.2)$ at the final follow-up visit, and no recurrence of erosive events was reported in any patient. The density of subbasal nerves was significantly reduced at 4 months, relative to the preoperative level $(\mathrm{P}=0.002)$. This reduction was followed by a significant increase from 4 to 8 months to return subbasal nerve density to the preoperative level $(\mathrm{P}=0.009)$. Superficial, wing, and basal epithelial cell density and subepithelial keratocyte density after PTK did not significantly differ from preoperative levels. When subgrouped by ablation depth, patients with a partial BL (compared to patients without BL) exhibited a less marked reduction in subbasal nerve density at 4 months, and more complete nerve regeneration at 8 months. In addition subepithelial keratocytes had a significantly higher density after total $\mathrm{BL}$ removal compared with partial BL removal at 8 months $(\mathrm{P}$ $=0.005$ ).

Study II: Clinical outcome and recurrence of epithelial basement membrane dystrophy after phototherapeutic keratectomy. In the cohort of EBMD patients, BSCVA at follow-up remained unchanged or improved in 49 of 51 eyes. BSCVA was 20/20 in 31 eyes, between 20/20 and 20/40 in 5 eyes, and worse than 20/40 in 2 eyes. Recurrence of EBMD was classified according to recurrence of symptoms (clinical recurrence), recurrence of pathology on slit lamp or IVCM images (morphologic recurrence), or either type (recurrence of any form). $24 / 52$ treated eyes had recurrence of any form of EBMD (7/52 eyes had clinical recurrence and 21/52 had morphological recurrence) in the PTK-treated eyes (1 to 8 years after surgery) (Figure 12). By exact logistic regression, the chance of recurrence (any form) significantly increased with follow-up time, and a similar effect was noted in the morphologic recurrence only group. Clinical recurrence was confirmed by positive IVCM findings (map, dot, or fingerprint features) in $3 / 7$ cases and by slit lamp findings in only $1 / 7$ of the cases. In 6/10 cases, a recurrence of EBMD morphologic features observed with the slit lamp was confirmed by IVCM. Conversely, in 11 cases where IVCM detected morphology consistent with EBMD, no confirmatory slit lamp evidence was found. Additionally, weak associations between morphologic recurrence and the presence of $\mathrm{BL}$ and laser epithelial removal were found. A grading scale for EBMD morphology by IVCM was developed. Of the 17 operated eyes with positive results for morphologic recurrence by IVCM, 9/17 eyes were classified as having grade 1 recurrence, $8 / 17$ eyes were classified as having grade 2 recurrence, and no operated eye had 
severe grade 3 morphologic recurrence by IVCM. By IVCM, 15/17 eyes had map features, 13/17 eyes had dots, and 11/17 eyes had both. No fingerprint lines were observed after surgery.

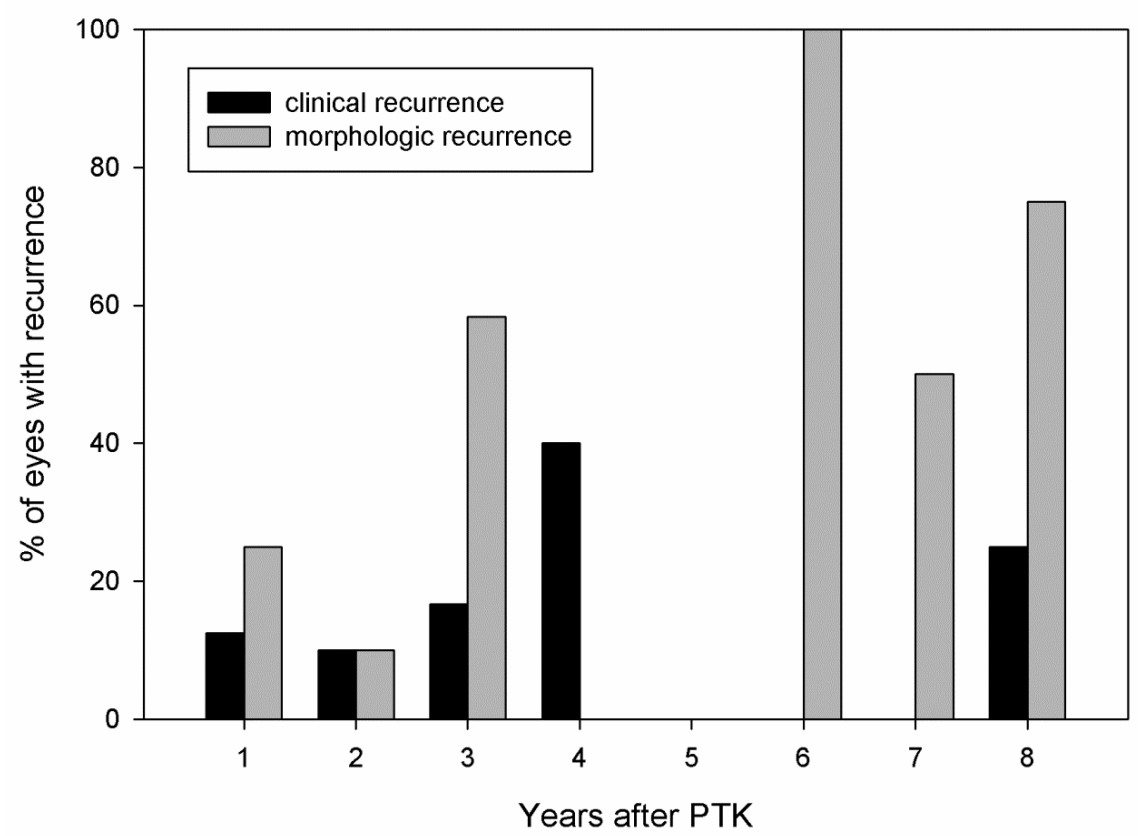

Figure 12. The proportion of treated eyes from the study cohort with recurrence in a given year after phototherapeutic keratectomy (PTK).

Study III: An accurate method to determine Bowman's layer thickness in vivo in the human cornea. In nine transplant patients, BL thickness of the cornea by IVCM prior to removal was $13.7 \pm 1.6 \mu \mathrm{m}$, using an initial method of in vivo image analysis (Method 1). This in vivo value was significantly greater than the value by LM in the same corneas after removal, which was $9.7 \pm 1.7 \mu \mathrm{m}(\mathrm{P}<$ 0.001). The correlation between BL thickness by LM and IVCM was poor. In 20 right eyes of 20 normal corneas, the initial method and a revised method of in vivo analysis (Method 2) were used to determine BL thickness. Mean BL thickness by Method 1 was found to produce significantly thicker values (13.2 \pm $1.6 \mu \mathrm{m})$, compared to Method $2(9.1 \pm 1.4 \mu \mathrm{m})$, however, the correlation between Method 1 and Method 2 was very strong. The revised in vivo method of BL thickness measurement in healthy corneas gave a result similar to the LM value in the patients. Upon careful observation, BL in LM and in vivo images was characterized by the lack of a distinct border between $\mathrm{BL}$ and the anterior stroma. Ultrastructural analysis by TEM revealed a gradual, indistinct transition of the disordered collagen fibrils of BL to the more ordered collagen lamellae of the anterior stroma. 
Study IV: Age-related thinning of Bowman's layer in the human cornea in vivo. In a large healthy cohort of 82 subjects, central corneal thickness by OCT was $535.4 \pm 31.3 \mu \mathrm{m}(\mathrm{RE})$ and $533.9 \pm 31.2 \mu \mathrm{m}(\mathrm{LE})$. Thickness in right and left eyes was highly correlated. No significant correlation of central corneal thickness was found with age or gender. BL thickness measured by IVCM (using the revised method from Study III) was significantly negatively correlated with subject age (Figure 13) in both right $(\mathrm{P}<0.0001)$ and left $(\mathrm{P}<0.0001)$ eyes. When subjects were grouped into those younger than or older than (or equal to) the mean age of $48 \mathrm{y}$, for both eyes, the Student's t-tests indicated that in older subjects (mean \pm SD age, $64.4 \pm 9.3$ years) BL thickness was significantly thinner (mean $\pm \mathrm{SD}, 8.6 \pm 1.7 \mu \mathrm{m}$ in right eyes and $8.4 \pm 1.9 \mu \mathrm{m}$ in left eyes) relative to that in younger subjects (mean $\pm \mathrm{SD}$ age, $31.6 \pm 7.6$ years) (mean $\pm \mathrm{SD}, 10.7 \pm 1.6 \mu \mathrm{m}$ in right eyes and $10.7 \pm 1.8 \mu \mathrm{m}$ in left eyes) $(\mathrm{P}<0.001$ for both eyes). The variation in BL thickness within groups remained at a constant 6 to $7 \mu \mathrm{m}$. In the healthy cornea, BL was on average $20 \%$ thinner in older subjects compared to younger subjects.

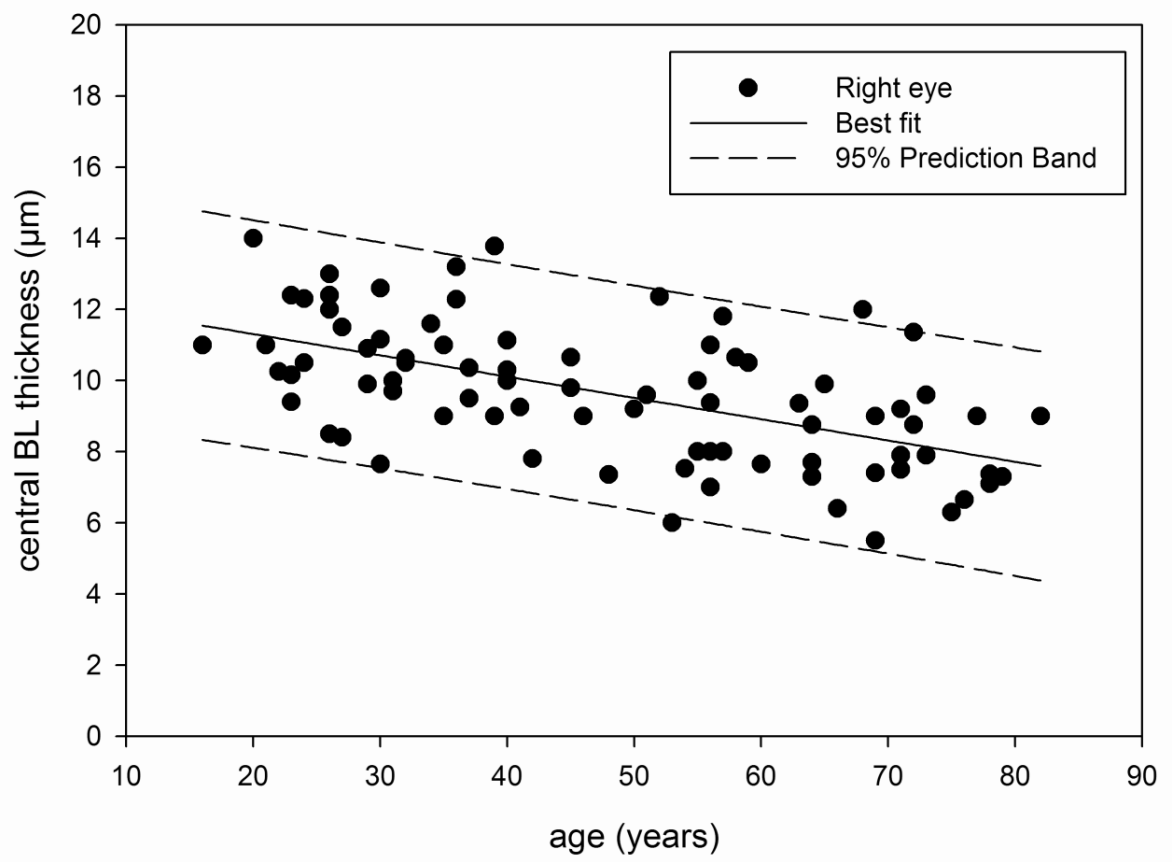

Figure 13. Decline in Bowman's layer (BL) thickness with age (in right eyes) of healthy subjects. The solid line indicates the best-fit linear regression line, while dashed lines indicate the $95 \%$ confidence intervals for BL thickness. BL thickness declined significantly with increasing age $(\mathrm{P}<0.0001)$. 
Study V: Pathologically reduced subbasal nerve density in epithelial basement membrane dystrophy is unaltered by phototherapeutic keratectomy treatment. Subbasal nerve density was significantly reduced in a cohort of 39 EBMD eyes treated by PTK (10 $\left.624 \pm 4479 \mu \mathrm{m} / \mathrm{mm}^{2}\right)$ and 24 non-operated, asymptomatic fellow EBMD eyes $\left(10164 \pm 4139 \mu \mathrm{m} / \mathrm{mm}^{2}\right)$, compared to normal healthy corneas $\left(18241 \pm 4479 \mu \mathrm{m} / \mathrm{mm}^{2}\right)(\mathrm{P}<0.001)$. Within the group of eyes with EBMD treated by PTK, mean subbasal nerve density was nearly identical to the untreated fellow eyes. Subbasal nerve density did not correlate with postoperative time, indicating a return to preoperative levels by the first year after PTK, and no further gain in subbasal nerve density beyond the preoperative level, even 8 years after PTK.

By both manual and automated methods of analysis, no significant difference could be found in the mean central epithelial wing cell density between PTK treated eyes and non-operated fellow eyes with EBMD. By the automated method however, epithelial wing cell density in PTK-treated corneas was significantly reduced (by approximately $5 \%$ ) relative to healthy corneas $(\mathrm{P}=0.008)$. 


\section{DISCUSSION}

Epithelial basement membrane dystrophy (EBMD) can be a complex condition to diagnose, document, and treat. The patient response to treatment can be equally complex. To gain deeper insight into EBMD and its treatment, one must understand its pathologic morphology in the epithelium, and the effect of treatment on this morphology. When investigating these issues, Bowman's layer (BL) emerges as an important parameter.

This thesis began with investigating the outcomes of treatment by phototherapeutic keratectomy (PTK) on EBMD and recurrent corneal erosions. This led to questions concerning BL and its role in wound healing, and in the recurrence of EBMD after PTK. The PTK procedure is performed by assuming a uniform and constant thickness of BL for all patients, and this assumption was brought into question as the studies in this thesis progressed. When investigating this issue closer, it was found that information regarding BL thickness in humans was scarce and inconsistent. The latter part of this thesis therefore focused on techniques to accurately measure BL thickness in humans, and to report its variability.

\section{Bowman's layer in corneal wound healing}

In Study I, the role of Bowman's layer on the nature of anterior corneal regeneration after PTK was examined using laser scanning in vivo confocal microscopy (IVCM). A delay in nerve regeneration was found in patients without BL relative to patients with a partial BL. BL was therefore thought to serve as a protective barrier to the underlying subepithelial nerve plexus. BL was also found to have an additional potential role in accelerating wound healing and return of transparency after epithelial trauma. One limitation of this study, howerver, was the small size of the groups. These results should ideally be confirmed in larger, prospective studies in the future.

The result of potential roles for BL were in contrast to an earlier hypothesis that BL did not have an important function, mainly because no significant complications arose after complete BL removal in hundreds of thousands of PRKtreated eyes [39]. In Study I, it was speculated that with complete BL removal, future epithelial trauma might prolong corneal wound healing. The results of Study I highlight the importance of finding a balance between partial BL removal to benefit nerves and wound healing on the one hand, and complete BL removal to avoid EBMD recurrence on the other. Ideally, it would be best to find an ablation depth that precisely removes BL completely, without affecting the underlying nerves and stroma. For such a precise surgery, PTK is the method of choice, however, exact BL thickness needs to be known. 


\section{Bowman's layer thickness}

There is a large discrepancy in BL thickness values in the literature, due to the variety of measurment techniques, resolution differences between instruments, and tissue preparation artifacts arising in ex vivo samples. Studies III and IV attempted to address several of these issues. By adopting a morphological approach to determine the boundaries of BL, deficiencies in previous in vivo methods of measurement were addressed. Moreover, using laser scanning confocal technology yielded higher contrast and higher magnification images than other in vivo techniques. We found that there was a thinning of BL with age and also that BL thickness may not be constant over the entire central cornea, particularly in pathologic cases. In the healthy cornea, a variation in BL thickness from person to person was also seen. The reason for this inter-individual variation might depend on several methodological limitations. This is a partially subjective measurement, which requires good quality images to interpret and locate the borders of BL. Even with the revised method 2, using a volume scan choosing one frame more in any direction, a difference of almost half the thickness of BL can occur. The inter-individual variation in BL thickness of 5-6 $\mu \mathrm{m}$ however was also found in LM sections. This result might be biased by the small number of subjects all with pathologic corneas, tissue preparation artefacts, and also subjective measurement. The question is, if all these potential biases were removed is there still a physiologic variability? A physiologic variability exists in total corneal thickness, so it is reasonable to assume the same for BL. The degree of variability, however, may be reduced if sources of bias were removed. Regardless, laser scanning IVCM is the best technique available today for measuring BL thickness, but finer axial resolution combined with a finer axial spacing of adjacent confocal images and better contrast should improve the accuracy even more.

Because of physiologic variation, individual assessment of BL should therefore ideally be performed prior to laser surgery of the anterior cornea. In Study III, it was found that high resolution laser scanning IVCM could be a viable technique to determine an accurate value for Bowman's layer thickness in vivo in humans. The values for BL thickness in vivo were close to values obtained by light microscopy in ex vivo fixed tissue sections. Although this result requires confirmation in larger studies with in vivo and ex vivo measurement of the same corneas, it is recommended that IVCM be used for assessment of BL, not only prior to PTK, but before other surgical treatments, such as UVA-riboflavin collagen crosslinking. One may find that BL is unexpectedly absent or very thin in some corneas, possibly impacting treatment. 


\section{IVCM diagnosing EBMD}

Because of its high resolution, IVCM is not only useful in assessing BL thickness, but it can be used to recognize pathologic morphology. In Study I and II, IVCM proved to have a potential role in diagnosing EBMD and in the differential diagnosis of EBMD from RCE. IVCM examination could therefore prevent patients with symptoms but no visible signs of EBMD on slit lamp examination to go undiagnosed and untreated.

\section{Outcome and recurrence of EBMD after PTK}

Clinically, PTK treatment of EBMD in Study II had a high success rate, with BSCVA remaining unchanged or improved in $98 \%$ of the cases. Symptomatic recurrence occurred in only $13 \%$ but did not warrant reoperation, and the morphologic severity grade decreased, completely abolishing all grade 3 EBMD features. Despite the clinical success of PTK, however, it was found that IVCM can detect recurrence of pathologic morphology even in patients without clinical symptoms, while confirming symptomatic recurrence despite negative slit lamp findings. Recurrence of clinical and/or morphological EBMD was found in $46 \%$ of the PTK treated eyes in Study II. It became obvious that a complex relationship exists between EBMD morphology and symptoms. To gain deeper understanding, a grading system was adopted for assessment of the severity of the EBMD morphologic features. We suggest that the grading system should be used routinely in the clinic in preoperative examinations of potential EBMD patients. The grading system can thereafter also be used for postoperative confirmation of surgical success and follow-up. To highlight the complexity of the disease, grade 3 morphologic features were also found in asymptomatic EBMD eyes in Study II, suggesting that other factors than the known morphologic features of EMBD today can cause the clinical symptoms. Future research in this area is necessary.

\section{Bowman's layer and recurrence of EBMD}

The recurrences might depend on several factors. For instance, the technique of laser epithelial removal in $42 \%$ of the eyes in Study II (assuming a fixed epithelial thickness of $55 \mu \mathrm{m}$ ), might not have removed all epithelia, creating shallow ablations. BL was in these cases found to remain, at least partially, in $50 \%$ of such cases after PTK. The uncertainty of reaching the BL when using laser epithelial removal might depend on the basal membrane in EBMD varying in thickness if it becomes multi laminar, thereby creating variations in the epithelial thickness. In addition, the ablation depth for BL removal was in the majority of cases set to a fixed depth of $15 \mu \mathrm{m}$, without preoperative assessment of BL thickness. Although ablation depth did not correlate with recurrence in this study, variability in BL thickness might be important to take into account.

Is retreatment an option when suspecting that shallow ablation is the cause of recurrence? Earlier studies reporting recurrent erosions after only partial removal 
of BL have showed resolution of symptoms after retreatment. [76, 81, 83]. In Study II, recurrence significantly increased with increasing postoperative time suggesting that PTK, if too shallow, may not be sufficient to prevent pathologic morphologic features from appearing in the long term, which could eventually lead to recurrence of clinical symptoms. Retreatment by PTK may therefore be a viable option in cases where symptoms arise and evidence (ablation depth, IVCM, or other) indicates that the first treatment may have been too shallow. An alternate hypothesis for the origin of recurrence in some cases, even where BL may be completely removed, could be a defective process of reattachment of new basement membrane to the underlying stroma, or formation of weaker attachments that eventually fail. The mechanisms of production of new basement membrane after ablation, and its subsequent attachment to underlying stroma, in both healthy and EBMD situations, warrants further investigation. The key for finding the right treatment is to gain more knowledge about the etiology of the disease. Can recurrence of EBMD be evidence that there might be multiple factors causing EBMD?

\section{Subbasal nerve density}

The reason for the high incidence of recurrence in Study II might also depend on new diagnostic technique using high-resolution laser scanning IVCM, which gives the opportunity to examine morphology in vivo at a much closer level then previously possible. This high-resolution ability also led to the finding in Study $\mathrm{V}$ that subbasal nerve density was significantly reduced in both PTK treated and untreated EBMD corneas in long term compared to a healthy population. These results indicate that a general deficit of subbasal nerves exists in EBMD. This might be the result of the basement membrane separation and folding thus preventing proper innervation, branching, and regeneration from the peripheral nerves. The potential clinical consequences of this neural deficit, in terms of ocular surface sensitivity, tear film parameters, and possibility for development of dry eye, requires closer examination. 


\section{CONCLUSIONS}

BL has a possible role in facilitating rapid stromal wound healing and an associated recovery of anterior corneal transparency and the restoration of epithelial innervation after epithelial trauma.

PTK is an effective method of alleviating the clinical symptoms of EBMD, but the dystrophy can recur with time. Reasons for this recurrence are unclear, but may be related to surgical parameters and to the pathophysiology of the disease.

It is possible to determine an accurate value for Bowman's layer thickness in vivo in the human cornea. We believe that the new method presented represents the most accurate means to date to determine BL thickness in vivo. With this method it was found that BL likely undergoes thinning with age.

Subbasal nerve density in EBMD is reduced by $45 \%$ relative to healthy corneas, and recovers only to the reduced level in the long term after PTK treatment. Epithelial wing cell density is not affected by EBMD or by PTK treatment.

Finally, regarding the general aim of this work, it is believed that the new knowledge gained from this thesis can improve clinical practice by the use of the IVCM for more accurate diagnosis and understanding of EBMD. Treatment and recurrence rate of EBMD can also be improved by preoperative IVCM examination of Bowman's layer thickness prior to PTK, to accurately plan for complete ablation of BL. 


\section{SVENSK SAMMANFATTNING}

\section{Bakgrund}

Hornhinnan är en genomskinlig kupolformad struktur belägen centralt $\mathrm{i}$ den främre delen av ögat. Hornhinnan möjliggör att ljus kommer in i ögat, den har en optisk funktion och bidrar till att upprätthålla den strukturella integriteten av ögat. Hornhinnan bidrar till cirka $2 / 3$ av ögats brytningskraft som tillsammans med linsen fokuserar ljus på näthinnan för att skapa en bild. Hornhinnans yta hjälper också till att skydda ögat mot infektioner och skador på djupare, inre strukturer. Den normala mänskliga hornhinnan är ca $520 \mu \mathrm{m}$ tjock i mitten och består av fem olika skikt (Figur 14).

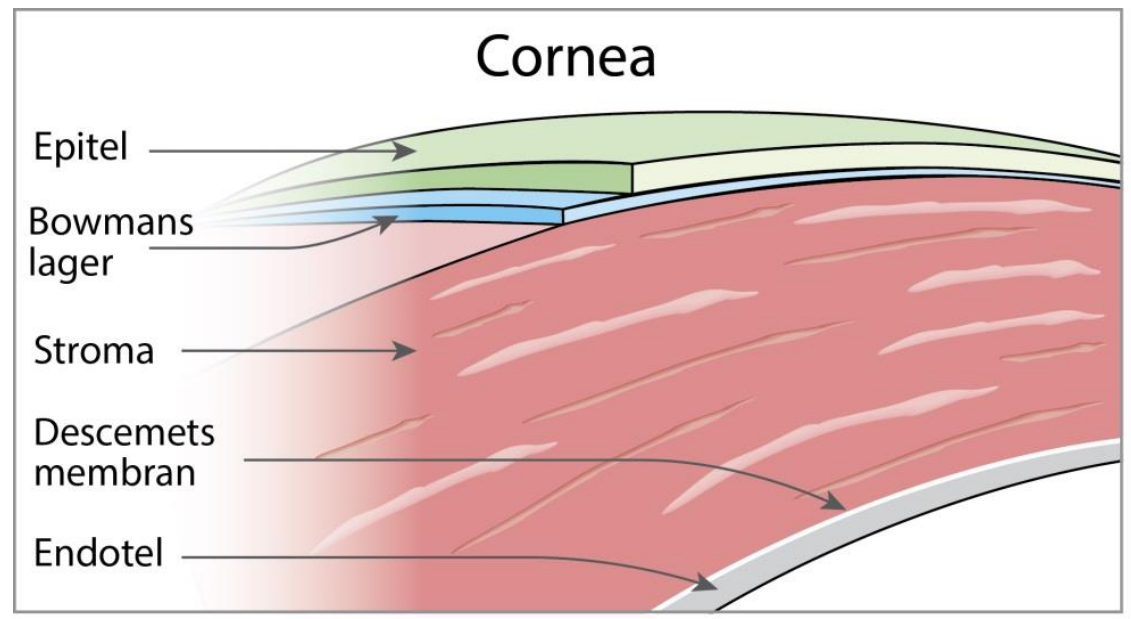

Figur 14. Hornhinnans uppbyggnad.

Epitelet är det yttersta skiktet. Det är ca $50 \mu \mathrm{m}$ tjockt och består av tre cellager innehållandes olika celltyper. Epitelets främre cellager består av ytliga epitelceller, därefter vingcellslagret och slutligen, det innersta skiktet av epitelet består av basala epitelceller. Epitelet är under ständig ombildning och förnyas på cirka 7 dagar. Basalcellerna ger upphov till ett basalmembran som vidhäftar epitelet till det underliggande Bowmans lager. Mellanskiktet stromat utgör $90 \%$ av hornhinnans tjocklek. Det består till största del av vatten, men även av celler (keratocyter), proteoglykaner och kollagen. Det innersta cellagret heter endotelet som avgränsas från stromat via Descemets membran. Hornhinnan består även av en stor mängd nerver som kommer in i höjd med stromalagret och tar sig upp till ytan. Nerverna utgör en viktig skyddande mekanism då de tillför känsel och initierar blinkreflexen. 
En hornhinnedystrofi definieras som en nedärvd, symmetrisk, progressiv, ickeinflammatorisk sjukdom utan relation till miljö eller systemiska faktorer. Dystrofin uppstår efter födseln och ska finnas i bägge ögonen. Det finns en stor mängd olika dystrofier.

Epitelial basalmembran dystrofi (EBMD) är den vanligaste dystrofin i hornhinnan. EBMD kännetecknas av kartliknande geografiska mönster, punktmönster eller fingeravtrycksliknande linjer i hornhinnans epitel. Dessa epitelförändringar uppstår på grund av defekt vidhäftning mellan epitelets basalmembran och Bowmans lager (Figur 15). De flesta patienterna märker ej av sjukdomen, men cirka $10 \%$ upplever synbesvär och/eller återkommande sår på hornhinnan. Många olika behandlingsmetoder har använts, men återkomst av sjukdomen är ett problem. Behandling med hjälp av laser på hornhinnan så kallad phototerapeutisk keratektomi (PTK) har blivit ett alltmer populärt kirurgiskt alternativ de senaste åren på grund av dess exakthet, reproducerbarhet och goda kirurgiska resultat. Vid behandling av EBMD med PTK påverkas ett område i hornhinnan som kallas Bowmans lager (BL). Ytterst lite är känt gällande Bowmans lagers funktion, egenskaper och faktiska tjocklek i levande vävnad.

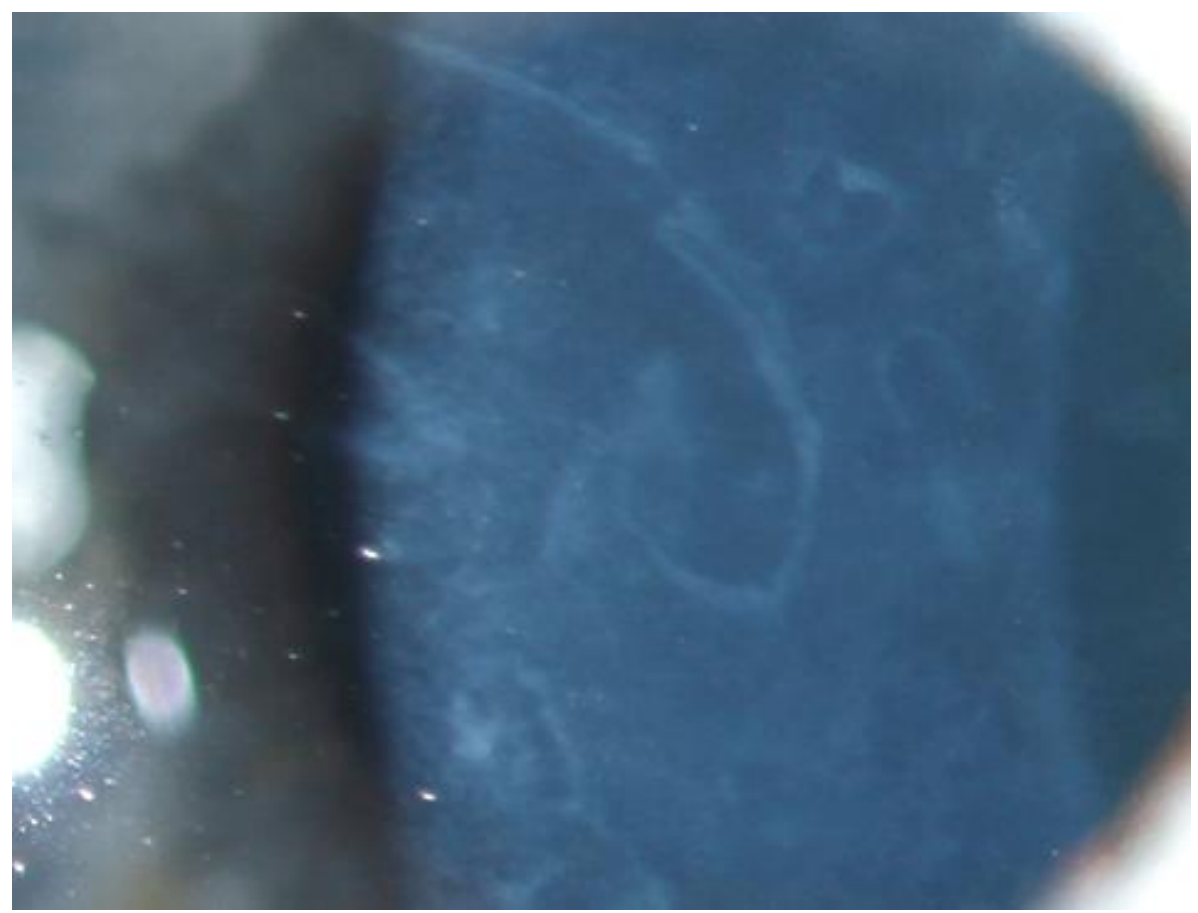

Figur 15. Epitelial basalmembran dystrofi ( EBMD ). Kartliknande geografiska mönster centralt på hornhinnan synligt i spaltlampemikroskop. 


\section{Syfte, material och metoder}

Syftet med denna avhandling var att få ytterligare kunskap gällande sjukdomen EBMD, PTK behandling av EBMD, samt Bowmans lager och dess relation till sjukdomen EBMD.

Metoden att genomföra undersökningarna involverade undersökningsteknik med ett konfokalmikroskop. Principen om konfokalmikroskopi uppfanns redan 1957 av Marvin Minskey, men det var inte förrän 1990 de första bilderna av mänsklig hornhinna i levande vävnad (in vivo) publicerades. Laser scanning in vivo konfokalmikroskop tillhör den senaste generationen konfakalmikroskop, där man i levande vävnad kan göra mätningar helt utan att påverka eller skada vävnaden. Hornhinnan är en perfekt vävnad för konfokalmikroskopi, på grund av dess genomskinlighet, tunna struktur och yttre anatomiska läge. Mikroskopet bygger på en teknik där bilder förvärvas punkt för punkt med hjälp av en fokuserad laser och rekonstrueras därefter i en dator. Man kan därför fokusera på en djupnivå i taget och undersöka strukturer och celler inuti hornhinnan i mycket hög upplösning så kallad optisk sektionering. Denna process skapar även möjligheten att bestämma ett exakt värde för Bowmans lagers tjocklek hos människa.

Fototerapeutisk keratektomi (PTK) är en kirurgisk behandling med en excimerlaser som genererar energi för att förstöra molekylbindningar i hornhinnans vävnad (ablation). Lasern tar bort all vävnad från ytan och inåt till ett i förväg bestämt djup. De vanligaste indikationerna för PTK är hornhinnedystrofier (inklusive EBMD), återkommande sårbildningar och ärr. En excimer laser (Technolas 217) användas för alla PTK behandlingar av EBMD patienter i våra studier.

\section{Resultat och diskussion}

IVCM kan vara ett användbart verktyg för screening avseende morfologi i hornhinnan före och efter hornhinnekirurgi hos EBMD patienter samt upptäcka tecken på sjukdom som inte upptäckts $\mathrm{i}$ ett konventionellt hornhinnemikroskop på kliniken. IVCM kan därför förhindra att patienter med symptom, men inga synliga tecken på EBMD vid undersökning med spaltlampa, förblir odiagnostiserade och obehandlade.

Vi visade att PTK är en effektiv metod för att lindra de kliniska symptomen på EBMD, men att dystrofin kan återkomma med tiden.

Bowmans lager visade sig vara viktigt när det gäller behandlingen och återkomsten av EBMD, efter att ha visat att vissa fall av EBMD patienter där enbart en del av BL blev borttaget under PTK operation inte var tillräckligt för att förhindra återfall av den bakomliggande sjukdomen. Resultaten visade också att det var en variation av Bowmans lagers tjocklek mellan olika individer samt att Bowmans lagers tjocklek minskar med åldern.

Vi skapade en ny mätmetod metod med hjälp av konfokalmikroskopet för att bestämma tjockleken av BL i levande vävnad. Denna metod kan senare bistå i 
klinisk bedömning och vara ett verktyg vid planerade av behandlingar av den främre hornhinnan.

Vi fann två potentiella funktioner för Bowmans lager. Vid en skada på hornhinnans yttersta lager epitelet kan BL utgöra en fysisk barriär som skyddar bakomliggande nervlager och därigenom påskyndar hornhinnans återväxt av nerver och känsel. Bowmans lager kan också fungera som en barriär som förhindrar direkt skadekontakt med hornhinnans inre lager (stromat) och därmed accelerera sårläkning och tillhörande återställande av hornhinnans celler och lager.

Genom att använda IVCM fann vi att nervtätheten minskade avsevärt $i$ både PTK-behandlade och obehandlade EBMD hornhinnor jämfört med en frisk befolkning. Dessa resultat indikerar att det finns ett allmänt underskott på nerverna hos EBMD patienter.

Ett fullt automatiserad program för att räkna celler i hornhinnans främre lager med hjälp av IVCM bilder skapades. Ett program som ger möjlighet att objektivt och standardiserat räkna och jämföra hornhinnans cellinnehåll i framtida forskning. 


\section{ACKNOWLEDGEMENTS}

I wish to express my sincere gratitude to:

Neil Lagali, my supervisor and friend, for your always positive attitude, kindness, effectiveness and teaching me the world of the confocal microscope, for being a brilliant tutor, writer and remarkable scientist.

Per Fagerholm, my supervisor, for introducing me and teaching me in the field of cornea, for believing in me and getting my scientific career started, for your patience in the operating room and for your vast knowledge and never ending enthusiasm.

Markus Karlsson, my roommate, good friend and colleague, for sharing my successes and setbacks, for always cheering me up, for a thousand word jokes.

Beatrice Bourghardt Peebo, my mentor, for being a source of inspiration, for stimulating discussions, thoughts and guidance in both career and personal life.

Marina Koulikovska, my co-author, for helping me in research and skilful assistance using the TEM.

Georgios Karanis, my co-author, for helping me in research and sharing your knowledge of the Greek kitchen.

Anette Dellby, for helping me with the corneal transplants and excimer laser.

Barbro Thoresson-Karlsson, for your laughter in the hallway and helping me with the many, many hours of recruitment, dialog and booking of patients.

Monica Johnsson, for excellent help, regardless of task and always with a smile. You are invaluable!

Per Lagman, for helping me with images and printing of this thesis in a remarkably quick and efficient way.

Mats Fredriksson, for help with the extremely difficult statistical analysis in study II.

Colleagues and friends at the Eye Clinic in Linköping, for all the help and advice during my career and working with this thesis. 
To ALL my friends, you know who you are; for a fantastic childhood, school years and present adult life. We do not always have a lot of time to spend, but it is always the best.

My loving parents and family, for all the love and support throughout my life and career, for always believing in me. You are the reason this thesis exists.

My brother Erik, for being the best brother anyone could wish for, for always having my back.

My wonderful children, Tyra, Gustav and Oskar, my stars, the joys of my life.

Maria, the love of my life, my best friend and wife, for always being by my side, and supporting me with love and "can do mentality".

Important financial support was received from:

County Council of Östergötland

Kronprinssan Margaretas Arbetsnämnd (KMA)

Synskadades Väl

The Swedish Research Council (Vetenskapsrådet, VR)

Konung Gustaf V:s och Drottning Victorias Frimurarestiftelse

Carmen and Bertil Regnérs Foundation (NL)

European Union Marie Curie Fellowship, European Commission, Brussels, Belgium (NL).

Cronqvist Foundation (NL) 


\section{REFERENCES}

1. Klyce S, Beuerman R. Structure and function of the cornea. Kaufman HE, Barron BA, McDonald MB, Waltman SR, eds. The Cornea. New York: Churchill Livingstone. 1988:3-54.

2. Sabet S, Adamopoulou C. Basic structure and function of the human cornea and adnexal structures. Copeland RA, Afshari NA, eds. Principles and practice of cornea. New Delhi: Jaypee-Highligts medical publishers, inc. 2013;1(1):1-15.

3. Duong H. Corneal embryology. Copeland RA, Afshari NA, eds. Principles and practice of cornea. New Delhi: Jaypee-Highligts medical publishers, inc. 2013:16-25.

4. Ehlers N, Heegaard S, Hjortdal J, Ivarsen A, Nielsen K, Prause JU. Morphological evaluation of normal human corneal epithelium. Acta ophthalmologica. 2010;88(8):858-861.

5. Duong $\mathrm{H}$. The human cornea: Basic structure and function. Copeland RA, Afshari NA, eds. Principles and practice of cornea. New Delhi: JaypeeHighligts. 2013:26-42.

6. Davanger M, Evensen A. Role of the pericorneal papillary structure in renewal of corneal epithelium. Nature. 1971;229(5286):560-561.

7. Auran JD, Koester CJ, Kleiman NJ, et al. Scanning slit confocal microscopic observation of cell morphology and movement within the normal human anterior cornea. Ophthalmology. 1995;102(1):33-41.

8. Thoft RA, Friend J. The X, Y, Z hypothesis of corneal epithelial maintenance. Investigative ophthalmology \& visual science. 1983;24(10):1442-1443.

9. Dua H, Miri A, Said D. Limbal stem cells of the corneal epithelium. Copeland RA, Afshari NA, eds. Principles and practice of cornea. New Delhi: Jaypee-Highligts medical publishers, inc. 2013:80-86.

10. Hanna C, Bicknell DS, O'Brien JE. Cell turnover in the adult human eye. Archives of ophthalmology. 1961;65:695-698.

11. Zhivov A, Stave J, Vollmar B, Guthoff R. In vivo confocal microscopic evaluation of Langerhans cell density and distribution in the normal human corneal epithelium. Graefe's archive for clinical and experimental ophthalmology. 2005;243(10):1056-1061.

12. Khodadoust AA, Silverstein AM, Kenyon DR, Dowling JE. Adhesion of regenerating corneal epithelium. The role of basement membrane. American journal of ophthalmology. 1968;65(3):339-348.

13. Brewitt H, Reale E. The basement membrane complex of the human corneal epithelium. Albrecht von Graefe's archive for clinical and experimental ophthalmology. 1981;215(4):223-231.

14. Kenyon K. Morphology and pathologic responses of the cornea to disease. Smolin G, Thoft RA, eds. The Cornea. Scientific Foundations and Clinical Practice. Boston: Little, Brown \& Co 1983:43-75. 
15. DelMonte DW, Kim T. Anatomy and physiology of the cornea. Journal of cataract and refractive surgery. 2011;37(3):588-598.

16. Michelacci YM. Collagens and proteoglycans of the corneal extracellular matrix. Braz J Med Biol Res. 2003;36(8):1037-46.

17. Marshall GE, Konstas AG, Lee WR. Immunogold fine structural localization of extracellular matrix components in aged human cornea. I. Types I-IV collagen and laminin. Graefe's archive for clinical and experimental ophthalmology. 1991;229(2):157-163.

18. Hassell JR, Birk DE. The molecular basis of corneal transparency. Experimental eye research. 2010;91(3):326-335.

19. Boote C, Kamma-Lorger CS, Hayes S, et al. Quantification of collagen organization in the peripheral human cornea at micron-scale resolution. Biophysical journal. 2011;101(1):33-42.

20. Meek KM, Boote $\mathrm{C}$. The organization of collagen in the corneal stroma. Experimental eye research. 2004;78(3):503-512.

21. Murphy C, Alvarado J, Juster R. Prenatal and postnatal growth of the human Descemet's membrane. Investigative ophthalmology \& visual science. 1984;25(12):1402-1415.

22. Johnson DH, Bourne WM, Campbell RJ. The ultrastructure of Descemet's membrane. I. Changes with age in normal corneas. Archives of ophthalmology. 1982;100(12):1942-1947.

23. Muller LJ, Marfurt CF, Kruse F, Tervo TM. Corneal nerves: structure, contents and function. Experimental eye research. 2003;76(5):521-542.

24. Schimmelpfennig B. Nerve structures in human central corneal epithelium. Graefe's archive for clinical and experimental ophthalmology. 1982;218(1):14-20.

25. Patel DV, McGhee CN. Mapping of the normal human corneal sub-Basal nerve plexus by in vivo laser scanning confocal microscopy. Investigative ophthalmology \& visual science. 2005;46(12):4485-4488.

26. Niederer RL, Perumal D, Sherwin T, McGhee CN. Age-related differences in the normal human cornea: a laser scanning in vivo confocal microscopy study. The British journal of ophthalmology. 2007;91(9):1165-1169.

27. Muller LJ, Pels L, Vrensen GF. Ultrastructural organization of human corneal nerves. Investigative ophthalmology \& visual science. 1996;37(4):476-488.

28. Marfurt CF, Cox J, Deek S, Dvorscak L. Anatomy of the human corneal innervation. Experimental eye research. 2010;90(4):478-492.

29. Cruzat A, Pavan-Langston D, Hamrah P. In vivo confocal microscopy of corneal nerves: analysis and clinical correlation. Seminars in ophthalmology. 2010;25(5-6):171-177.

30. Guthoff RF, Wienss H, Hahnel C, Wree A. Epithelial innervation of human cornea: a three-dimensional study using confocal laser scanning fluorescence microscopy. Cornea. 2005;24(5):608-613.

31. Lerche $\mathrm{W}$, Wulle KG. Electron microscopic studies on the development of the human lens. Ophthalmologica. Journal international d'ophtalmologie. 
International journal of ophthalmology. Zeitschrift fur Augenheilkunde. 1969;158(4):296-309.

32. Tisdale AS, Spurr-Michaud SJ, Rodrigues M, Hackett J, Krachmer J, Gipson IK. Development of the anchoring structures of the epithelium in rabbit and human fetal corneas. Investigative ophthalmology \& visual science. 1988;29(5):727-736.

33. Marshall GE, Konstas AG, Lee WR. Immunogold fine structural localization of extracellular matrix components in aged human cornea. II. Collagen types V and VI. Graefe's archive for clinical and experimental ophthalmology. 1991;229(2):164-171.

34. Gordon MK, Foley JW, Birk DE, Fitch JM, Linsenmayer TF. Type V collagen and Bowman's membrane. Quantitation of mRNA in corneal epithelium and stroma. The Journal of biological chemistry. 1994;269(40):24959-24966.

35. Nakayasu K, Tanaka M, Konomi H, Hayashi T. Distribution of types I, II, III, IV and V collagen in normal and keratoconus corneas. Ophthalmic research. 1986;18(1):1-10.

36. Jacobsen IE, Jensen OA, Prause JU. Structure and composition of Bowman's membrane. Study by frozen resin cracking. Acta Ophthalmol (Copenh). 1984;62(1):39-53.

37. Hayashi S, Osawa T, Tohyama K. Comparative observations on corneas, with special reference to Bowman's layer and Descemet's membrane in mammals and amphibians. Journal of morphology. 2002;254(3):247-258.

38. Obata H, Tsuru T. Corneal wound healing from the perspective of keratoplasty specimens with special reference to the function of the Bowman layer and Descemet membrane. Cornea. 2007;26(9 Suppl 1):S8289.

39. Wilson SE, Hong JW. Bowman's layer structure and function: critical or dispensable to corneal function? A hypothesis. Cornea. 2000;19(4):417420.

40. Komai $\mathrm{Y}$, Ushiki $\mathrm{T}$. The three-dimensional organization of collagen fibrils in the human cornea and sclera. Investigative ophthalmology \& visual science. 1991;32(8):2244-2258.

41. Li HF, Petroll WM, Moller-Pedersen T, Maurer JK, Cavanagh HD, Jester $\mathrm{JV}$. Epithelial and corneal thickness measurements by in vivo confocal microscopy through focusing (CMTF). Current eye research. 1997;16(3):214-221.

42. Tao A, Wang J, Chen Q, et al. Topographic thickness of Bowman's layer determined by ultra-high resolution spectral domain-optical coherence tomography. Investigative ophthalmology \& visual science. 2011;52(6):3901-3907.

43. Eden U, Fagerholm P, Danyali R, Lagali N. Pathologic epithelial and anterior corneal nerve morphology in early-stage congenital aniridic keratopathy. Ophthalmology. 2012;119(9):1803-1810.

44. Patel DV, McGhee CN. In vivo laser scanning confocal microscopy confirms that the human corneal sub-basal nerve plexus is a highly dynamic 
structure. Investigative ophthalmology \& visual science. 2008;49(8):34093412.

45. Patel DV, McGhee CN. In vivo confocal microscopy of human corneal nerves in health, in ocular and systemic disease, and following corneal surgery: a review. The British journal of ophthalmology. 2009;93(7):853860.

46. Patel DV, McGhee CN. Mapping the corneal sub-basal nerve plexus in keratoconus by in vivo laser scanning confocal microscopy. Investigative ophthalmology \& visual science. 2006;47(4):1348-1351.

47. Smolin G. Dystrophies and degenerations. Smolin G, Thoft RA, eds. The Cornea. Scientific Foundations and Clinical Practice. Boston: Little, Brown \& Co. 1983:329-353.

48. Brown N, Copeland Jr R. Corneal and conjuntival degenerations. Copeland RA, Afshari NA, eds. Principles and practice of cornea. New Delhi: Jaypee-Highligts medical publishers, inc. 2013:805-818.

49. Waring GO, 3rd, Rodrigues MM, Laibson PR. Corneal dystrophies. I. Dystrophies of the epithelium, Bowman's layer and stroma. Survey of ophthalmology. 1978;23(2):71-122.

50. Weiss JS, Moller HU, Lisch W, et al. The IC3D classification of the corneal dystrophies. Cornea. 2008;27 Suppl 2:S1-83.

51. Fogle JA, Kenyon KR, Stark WJ, Green WR. Defective epithelial adhesion in anterior corneal dystrophies. American journal of ophthalmology. 1975;79(6):925-940.

52. Cogan DG, Kuwabara T, Donaldson DD, Collins E. Microcystic dystrophy of the cornea. A partial explanation for its pathogenesis. Archives of ophthalmology. 1974;92(6):470-474.

53. Dark AJ. Cogan's microcystic dystrophy of the cornea: ultrastructure and photomicroscopy. The British journal of ophthalmology. 1978;62(12):821830.

54. Brodrick JD, Dark AJ, Peace GW. Fingerprint dystrophy of the cornea. A histologic study. Archives of ophthalmology. 1974;92(6):483-489.

55. Rodrigues MM, Fine BS, Laibson PR, Zimmerman LE. Disorders of the corneal epithelium. A clinicopathologic study of dot, geographic, and fingerprint patterns. Archives of ophthalmology. 1974;92(6):475-482.

56. Hernandez-Quintela E, Mayer F, Dighiero P, et al. Confocal microscopy of cystic disorders of the corneal epithelium. Ophthalmology1998;105(4):631636.

57. Gipson IK. Adhesive mechanisms of the corneal epithelium. Acta ophthalmologica. Supplement. 1992(202):13-17.

58. Ehlers N, Moller HU. Dot-map-fingerprint dystrophy--Cogan's microcystic dystrophy--normal reactions of the corneal epithelium? Acta ophthalmologica. Supplement. 1987;182:62-66.

59. Hillenaar $T$, van Cleynenbreugel $H$, Remeijer $L$. How normal is the transparent cornea? Effects of aging on corneal morphology. Ophthalmology. 2012;119(2):241-248. 
60. Cavanaugh TB, Lind DM, Cutarelli PE, et al. Phototherapeutic keratectomy for recurrent erosion syndrome in anterior basement membrane dystrophy. Ophthalmology. 1999;106(5):971-976.

61. Rubinfeld R, Petkar A. Recurrent corneal erosion syndrome. Copeland RA, Afshari NA, eds. Principles and practice of cornea. New Delhi: JaypeeHighligts medical publishers, inc. 2013:497-508.

62. Jackson H. Effect of eye-pads on healing of simple corneal abrasions. British medical journal. 1960;2(5200):713.

63. Hammar B, Bjorck E, Lagerstedt K, Dellby A, Fagerholm P. A new corneal disease with recurrent erosive episodes and autosomal-dominant inheritance. Acta ophthalmologica. 2008;86(7):758-763.

64. Brown N, Bron A. Recurrent erosion of the cornea. The British journal of ophthalmology. 1976;60(2):84-96.

65. Tripathi RC, Bron AJ. Ultrastructural study of non-traumatic recurrent corneal erosion. The British journal of ophthalmology. 1972;56(2):73-85.

66. Dursun D, Kim MC, Solomon A, Pflugfelder SC. Treatment of recalcitrant recurrent corneal erosions with inhibitors of matrix metalloproteinase-9, doxycycline and corticosteroids. American journal of ophthalmology. 2001;132(1):8-13.

67. Wood TO, Griffith ME. Surgery for corneal epithelial basement membrane dystrophy. Ophthalmic surgery. 1988;19(1):20-24.

68. McLean EN, MacRae SM, Rich LF. Recurrent erosion. Treatment by anterior stromal puncture. Ophthalmology. 1986;93(6):784-788.

69. Tsai TY, Tsai TH, Hu FR, Hou YC. Recurrent corneal erosions treated with anterior stromal puncture by neodymium: yttrium-aluminum-garnet laser. Ophthalmology. 2009;116(7):1296-1300.

70. Sridhar MS, Rapuano CJ, Cosar CB, Cohen EJ, Laibson PR. Phototherapeutic keratectomy versus diamond burr polishing of Bowman's membrane in the treatment of recurrent corneal erosions associated with anterior basement membrane dystrophy. Ophthalmology. 2002;109(4):674679.

71. Suri K, Kosker M, Duman F, Rapuano CJ, Nagra PK, Hammersmith KM. Demographic patterns and treatment outcomes of patients with recurrent corneal erosions related to trauma and epithelial and bowman layer disorders. Am J Ophthalmol. 2013;156(6):1082-1087.

72. Fagerholm P. Phototherapeutic keratectomy: 12 years of experience. Acta ophthalmologica Scandinavica. 2003;81(1):19-32.

73. Orndahl M, Fagerholm P, Fitzsimmons T, Tengroth B. Treatment of corneal dystrophies with excimer laser. Acta Ophthalmol (Copenh). 1994;72(2):235-240.

74. Orndahl MJ, Fagerholm PP. Phototherapeutic keratectomy for map-dotfingerprint corneal dystrophy. Cornea. 1998;17(6):595-599.

75. Dinh R, Rapuano CJ, Cohen EJ, Laibson PR. Recurrence of corneal dystrophy after excimer laser phototherapeutic keratectomy. Ophthalmology. 1999;106(8):1490-1497. 
76. Stewart OG, Pararajasegaram P, Cazabon J, Morrell AJ. Visual and symptomatic outcome of excimer phototherapeutic keratectomy (PTK) for corneal dystrophies. Eye (London, England). 2002;16(2):126-131.

77. Campos M, Nielsen S, Szerenyi K, Garbus JJ, McDonnell PJ. Clinical follow-up of phototherapeutic keratectomy for treatment of corneal opacities. American journal of ophthalmology. 15 1993;115(4):433-440.

78. Lohmann CP, Sachs H, Marshall J, Gabel VP. Excimer laser phototherapeutic keratectomy for recurrent erosions: a clinical study. Ophthalmic surgery and lasers. 1996;27(9):768-772.

79. Pogorelov P, Langenbucher A, Kruse F, Seitz B. Long-term results of phototherapeutic keratectomy for corneal map-dot-fingerprint dystrophy (Cogan-Guerry). Cornea. 2006;25(7):774-777.

80. Forster W, Atzler U, Ratkay I, Busse H. Therapeutic use of the 193-nm excimer laser in corneal pathologies. Graefe's archive for clinical and experimental ophthalmology. 1997;235(5):296-305.

81. Jain S, Austin DJ. Phototherapeutic keratectomy for treatment of recurrent corneal erosion. Journal of cataract and refractive surgery. 1999;25(12):1610-1614.

82. Josephson J, Lustbader J. Copeland RA, Afshari NA, eds. Principles and practice of cornea. New Delhi: Jaypee-Highligts medical publishers, inc. 2013:1165-1169.

83. Bernauer W, De Cock R, Dart JK. Phototherapeutic keratectomy in recurrent corneal erosions refractory to other forms of treatment. Eye (London, England). 1996;10 ( Pt 5):561-564.

84. Chow AM, Yiu EP, Hui MK, Ho CK. Shallow ablations in phototherapeutic keratectomy: long-term follow-up. Journal of cataract and refractive surgery. 2005;31(11):2133-2136.

85. Dua HS, Gomes JA, Singh A. Corneal epithelial wound healing. The British journal of ophthalmology. 1994;78(5):401-408.

86. Soong HK. Vinculin in focal cell-to-substrate attachments of spreading corneal epithelial cells. Archives of ophthalmology. 1987;105(8):11291132.

87. Gaffney E, Maini P, Sherratt J, Dale P. Wound healing in the corneal epithelium: biological mechanisms and mathematical models. Journal of Theoretical Medicine. 1997;1:13-23.

88. Campos M, Szerenyi K, Lee M, McDonnell JM, Lopez PF, McDonnell PJ. Keratocyte loss after corneal deepithelialization in primates and rabbits. Archives of ophthalmology. 1994;112(2):254-260.

89. Helena MC, Baerveldt F, Kim WJ, Wilson SE. Keratocyte apoptosis after corneal surgery. Investigative ophthalmology \& visual science. 1998;39(2):276-283.

90. Jester JV, Barry PA, Lind GJ, Petroll WM, Garana R, Cavanagh HD. Corneal keratocytes: in situ and in vitro organization of cytoskeletal contractile proteins. Investigative ophthalmology \& visual science. 1994;35(2):730-743. 
91. Fini ME, Stramer BM. How the cornea heals: cornea-specific repair mechanisms affecting surgical outcomes. Cornea. 2005;24(8 Suppl):S2S11.

92. Wilson SE, He YG, Weng J, et al. Epithelial injury induces keratocyte apoptosis: hypothesized role for the interleukin-1 system in the modulation of corneal tissue organization and wound healing. Experimental eye research. 1996;62(4):325-327.

93. Wilson SE, Kim WJ. Keratocyte apoptosis: implications on corneal wound healing, tissue organization, and disease. Investigative ophthalmology \& visual science. 1998;39(2):220-226.

94. Rexed U. Nerve regeneration in corneal grafts in the rabbit. The British journal of ophthalmology. 1951;35(2):89-97.

95. Erie JC, McLaren JW, Hodge DO, Bourne WM. Recovery of corneal subbasal nerve density after PRK and LASIK. American journal of ophthalmology. 2005;140(6):1059-1064.

96. Bohnke M, Thaer A, Schipper I. Confocal microscopy reveals persisting stromal changes after myopic photorefractive keratectomy in zero haze corneas. The British journal of ophthalmology. 1998;82(12):1393-1400.

97. Hollingsworth JG, Efron N, Tullo AB. A longitudinal case series investigating cellular changes to the transplanted cornea using confocal microscopy. Contact lens \& anterior eye : the journal of the British Contact Lens Association. 2006;29(3):135-141.

98. Richter A, Slowik C, Somodi S, Vick HP, Guthoff R. Corneal reinnervation following penetrating keratoplasty--correlation of esthesiometry and confocal microscopy. German journal of ophthalmology. 1996;5(6):513517.

99. Tervo T, Vannas A, Tervo K, Holden BA. Histochemical evidence of limited reinnervation of human corneal grafts. Acta Ophthalmol (Copenh). 1985;63(2):207-214.

100. Niederer RL, Perumal D, Sherwin T, McGhee CN. Corneal innervation and cellular changes after corneal transplantation: an in vivo confocal microscopy study. Investigative ophthalmology \& visual science. 2007;48(2):621-626.

101. Rao GN, John T, Ishida N, Aquavella JV. Recovery of corneal sensitivity in grafts following penetrating keratoplasty. Ophthalmology. 1985;92(10):1408-11.

102. Jalbert I, Stapleton F, Papas E, Sweeney DF, Coroneo M. In vivo confocal microscopy of the human cornea. The British journal of ophthalmology. 2003;87(2):225-236.

103. Cavanagh HD, Jester JV, Essepian J, Shields W, Lemp MA. Confocal microscopy of the living eye. The CLAO journal : official publication of the Contact Lens Association of Ophthalmologists, Inc. 1990;16(1):65-73.

104. Niederer RL, McGhee CN. Clinical in vivo confocal microscopy of the human cornea in health and disease. Progress in retinal and eye research. 2010;29(1):30-58. 
105. Guthoff RF, Zhivov A, Stachs O. In vivo confocal microscopy, an inner vision of the cornea - a major review. Clinical \& experimental ophthalmology. 2009;37(1):100-117.

106. Lagali N, Bourghardt-Peebo B, Germundsson J, et al. Laser-Scanning in vivo Confocal Microscopy of the Cornea: Imaging and Analysis Methods for Preclinical and Clinical Applications. Confocal Laser Microscopy Principles and Applications in Medicine, Biology, and the Food Sciences, Ph.D. Neil Lagali (Ed.). InTech. 2013:51-80.

107. Labbe A, Liang H, Martin C, Brignole-Baudouin F, Warnet JM, Baudouin C. Comparative anatomy of laboratory animal corneas with a newgeneration high-resolution in vivo confocal microscope. Current eye research. 2006;31(6):501-509.

108. Lagali NS, Griffith $M$, Shinozaki N, Fagerholm P, Munger R. Innervation of tissue-engineered corneal implants in a porcine model: a 1-year in vivo confocal microscopy study. Investigative ophthalmology \& visual science. 2007;48(8):3537-3544.

109. Liang H, Brignole-Baudouin F, Labbe A, Pauly A, Warnet JM, Baudouin C. LPS-stimulated inflammation and apoptosis in corneal injury models. Molecular vision. 2007;13:1169-1180.

110. Bourghardt Peebo B, Fagerholm P, Traneus-Rockert C, Lagali N. Timelapse in vivo imaging of corneal angiogenesis: the role of inflammatory cells in capillary sprouting. Investigative ophthalmology \& visual science. 2011;52(6):3060-3068.

111. Peebo BB, Fagerholm P, Traneus-Rockert C, Lagali N. Cellular-level characterization of lymph vessels in live, unlabeled corneas by in vivo confocal microscopy. Investigative ophthalmology \& visual science. 2010;51(2):830-835.

112. Peebo BB, Fagerholm $P$, Lagali N. Transient anterior corneal deposits in a human immunodeficiency virus-positive patient. Cornea. 2010;29(11):1323-1327.

113. Peebo BB, Fagerholm P, Traneus-Rockert C, Lagali N. Cellular level characterization of capillary regression in inflammatory angiogenesis using an in vivo corneal model. Angiogenesis. 2011;14(3):393-405.

114. Erie JC, Hodge DO, Bourne WM. Confocal microscopy evaluation of stromal ablation depth after myopic laser in situ keratomileusis and photorefractive keratectomy. Journal of cataract and refractive surgery. 2004;30(2):321-325.

115. Knappe S, Stachs O, Zhivov A, Hovakimyan M, Guthoff R. Results of confocal microscopy examinations after collagen cross-linking with riboflavin and UVA light in patients with progressive keratoconus. Ophthalmologica. Journal international d'ophtalmologie. International journal of ophthalmology. Zeitschrift fur Augenheilkunde. 2011;225(2):95104.

116. Abramoff $M$, Magalhaes $P$, Ram S. Image processing with ImageJ. Biophotonics Int. 2004;11:36-42. 
117. Brumm, M. and S. Mian, Corneal pachymetry. Copeland RA, Afshari NA, eds. Principles and practice of cornea. New Delhi: Jaypee-Highligts medical publishers, inc. 2013: p. 98-111.

118. Meijering E, Jacob M, Sarria JC, Steiner P, Hirling H, Unser M. Design and validation of a tool for neurite tracing and analysis in fluorescence microscopy images. Cytometry. Part $A$ : the journal of the International Society for Analytical Cytology. 2004;58(2):167-176.

119. Labbe A, De Nicola R, Dupas B, et al. Epithelial basement membrane dystrophy: evaluation with the HRT II Rostock Cornea Module. Ophthalmology 2006;113:1301-8.

120. Ray WA, O'Day DM. Statistical analysis of multi-eye data in ophthalmic research. Investigative ophthalmology \& visual science. 1985;26(8):11861188 .

121. Murdoch IE, Morris SS, Cousens SN. People and eyes: statistical approaches in ophthalmology. The British journal of ophthalmology. 1998;82(8):971-973.

122. Bland JM, Altman DG. Statistical methods for assessing agreement between two methods of clinical measurement. Lancet. 1986;1(8476):307310. 
APPENDIX I-V 



\section{Papers}

The articles associated with this thesis have been removed for copyright reasons. For more details about these see:

http://urn.kb.se/resolve?urn=urn:nbn:se:liu:diva-106248 